Estuarine, Coastal and Shelf Science

March 2015, Volume 155, Pages 89-103

http://dx.doi.org/doi:10.1016/i.ecss.2014.12.044

http://archimer.ifremer.fr/doc/00249/36034/

(c) 2015 Elsevier Ltd. All rights reserved.

\title{
Contrasting tropical estuarine ecosystem functioning and stability: A comparative study
}

\author{
Villanueva Maria Ching ${ }^{1,{ }^{*}}$ \\ ${ }^{1}$ IFREMER, Centre de Brest, Sciences et Technologies Halieutiques, BP 70, 29280, Plouzané, France \\ * Corresponding author: Maria Ching Villanueva, Tel.: +33298224040 ; \\ email address : ching.villanueva@ifremer.fr
}

\begin{abstract}
:
A comparative study of the Sine-saloum (Senegal) and Gambia (The Gambia) estuaries was performed based on trophic model outputs that describe the system structure and functioning. These trophic models were constructed such as to differentiate main energetic flows in the systems and express how climate change may have impacted ecosystem resilience to change. Estuarine fish assemblages are highly resilient despite exposure to vast hydrodynamic variations and stress. Coupled with strong anthropogenic-driven stresses such as fisheries and climate change, ecosystems may undergo severe regime shifts that may weaken their resilience and stability. Taxonomically related and morphologically similar species do not necessarily play similar ecological roles in these two ecosystems. Biomass and production in the Sine-saloum are concentrated at trophic levels (TLs) 2 and 3, while for the Gambia, both are concentrated at TL3. Higher TL biomasses in Gambia compared to Sine-Saloum may be explained by the latter ecosystem being characterized by inverse hypersalinity. Higher TL of production in Sine-Saloum is due to higher exploitations compared to Gambia where fishing activities are still less developed. High production and consumption rates of some groups in both ecosystems indicate high system productivity. Elevated productivity may be due to higher abundance of juvenile fishes in most groups that utilize the latter as refuge and/or nursery zones. Both ecosystems are phytoplankton-driven. Differences in group trophic and ecological roles are mainly due to adaptive responses of these species to seasonal and long-term climate and anthropogenic stressors. System indicators suggest different levels of ecosystem resilience and stability as a function of biodiversity. Relevance of other observations on ecosystem functioning and indicators in relation to perturbation is discussed.
\end{abstract}

Keywords : complex adaptative systems, climate change, food web models, regime shifts, ecosystem resilience, trophic ecology 
Introduction

Tropical estuaries are considered as biogeochemical hotspots due to high levels of primary production, large reserves of organic matter and habitat diversity that offer optimal niches for numerous aquatic species which utilize these areas as refuge and/or nursery grounds and anthropogenic pressures on ecosystems (Baran 2000; Cloern et al. 2013). Production in estuaries and coastal lagoons tend to be 10-15 times higher than those of other continental shelves (Duarte 1995).

As transitional areas with intense fluctuations of environmental conditions, these ecosystems influence multi-species dynamics and impose physiological constraints on biota (Baran 2000). Estuaries are often shallow with highly varying hydrological regimes and are structured by marine-freshwater inflows and bio-geographic regions (Whitfield et al. 2012). Biodiversity varies as a function of marine and/or continental water flows into these 'intermediate' systems (Blaber 2002; Deegan and Garritt 1997). Species abundance trends tend to decrease as salt marshes increase (Ferreira et al. 2005; Struyf et al. 2004). Changes in environmental conditions generally provoke diverse biological responses, allowing only tolerant species to persist (Glaser 2003; Taylor et al. 2014).

Drivers to ecosystem changes include natural and anthropogenic processes. Due to their location, and the multitude of ecological services they provide, estuarine areas often attract large human populations, and thus the risks of environment degradation are 
also high (Glaser 2003; Lotze et al. 2006). In developing countries, development of artisanal/traditional and industrialized fisheries and aquaculture in these ecosystems have also been growing, to meet increasing demand for local consumption and export (Lalèyè et al. 2007; Welcomme 2002). However, fisheries usually target not only highly commercial stocks, but also impacts forage species, consequently impacting the dynamics of the entire ecosystem (Sadovy 2001).

Apart from fisheries, another human-related threat to coastal wetlands is climate change. Five estuarine environmental factors can be impacted as a response to climate change: sea level, intensity and frequency of rainfall, salinity, freshwater-sedimentsnutrients inputs and water circulation (Kennedy 1990). Negative impacts of seasonal hydrologic regimes (Ponce Campus et al. 2013; Taylor et al. 2014) and global climate change (Alongi 2008; James et al. 2013; Kennedy 1990) on estuaries are well documented. Changes affect individual bio-ecological processes (i.e., osmoregulation, growth, reproduction) and community abundance and distribution. These ecogeomorphological alterations can have negative impact on biodiversity that can disrupt system integrity, leading to changes in structure, functioning, dynamics and productivity (Ferreira et al. 2005; Roessig et al. 2004).

In this study, two West African estuaries are considered and compared. As transitional ecosystems, they are noted for their high taxonomic richness due to a succession of species utilizing these environments as nurseries and refugia. Due to the limited geographical distance between these estuaries, close similarities of marine and estuarine fish faunas have been observed (Baran 2000). However, differences in hydrological regimes have led to contrasting observations on fish ecology and utilization of these environments (Diouf 1996; Panfili et al. 2006; Vidy 2000; Vidy et al. 2004; Villanueva 2004). 
As highly productive and complex ecosystems, knowledge on the biological and ecological functioning of fish faunas utilizing, as well as, the environmental forces contributing to geographic specificities of these environments is vital for sustainable management and conservation of these ecosystems. Recognizing that anthropogenic activities impact not only on the environment, but the dynamics and functioning of its living resources, untangling ecosystem processes can increase understanding on its current health and resilience to change. An ecosystem-based approach that can synthesize multi-specific analyses and the combined influence of their characteristics (i.e., production, mortality, trophic interactions, physiological adaptation, etc.) following environmental changes can be valuable to understand and manage such fragile ecosystems (Imperial and Hennessey 1996).

This study attempts to summarize and integrate existing data and to draw a larger picture of interactions among biological components and how abiotic conditions mould the structure and functioning of these ecosystems. This is also a comparative study of two systems with severely contrasting hydrological regimes: a 'normal', less exploited estuary (The Gambia) and an 'inverse hypersaline', highly exploited system (SineSaloum). Trophic models of these ecosystems are constructed in order to quantify energetic flows, trophodynamic links and transfer efficiencies among trophic levels $(T L s)$ and identify differences in the species ecological functioning and ecosystem structure as adaptive response to contrasting hydrological regimes. Modelling ecological systems can be valuable in describing how an ecosystem is organized and how changes can affect system internal processes (Berlow et al. 2004). Modelling can also provide indicators to assess risks on ecosystem stability and biodiversity through the complex, but tractable depictions of energy transfers, trophic fluxes, assimilation efficiencies and dissipation (Rambouts et al. 2013). Results can provide critical insights that can be 
further utilized to evaluate the impacts of changes in biodiversity (Balvanera et al. 2006;

Christian et al. 2005), ecosystem structure and functioning (Roessig et al. 2004;

Villanueva et al. 2006) and verify multi-species management decisions and conservation

(Brando et al. 2004; Imperial and Hennessey 1996).

\section{Methods}

\section{Study sites}

The Sine-Saloum estuary (Figure 1a) is $100 \mathrm{~km}$ south of Dakar, Senegal, 135' and $14^{\circ} 10^{\prime} \mathrm{N}$ and $16^{\circ} 03^{\prime}$ and $16^{\circ} 50^{\prime} \mathrm{W}$. It has a total area of approx. $543 \mathrm{~km}^{2}$ opening into the Atlantic Ocean. As an inland type, deltaic system, it is characterized by flat river valleys with varying water levels depending on seasonal floods from adjacent marine ecosystems. It consists of three main branches from north to south: Saloum, Diomboss and Bandiala. At the western end of these branches are characterized by a network of fine creeks (locally called 'bolongs') dominated by dense mangrove trees. The Saloum extends up to $180 \mathrm{~km}$ with water depths from $25 \mathrm{~m}$ (mouth) to $13 \mathrm{~m}$ (upstream), while Diomboss and Bandiala have maximum water depths of $10 \mathrm{~m}$. Water hypersalinity was a result of a perennial 'El Niño phenomenon' that had completely cut-off freshwater inputs (Pagès and Citeau 1990; Simier et al. 2004). Aside from the system geomorphology, the inverse hypersalinity effect is due to small freshwater inflows, not compensating for a high evaporation. Water salinity in upstream areas can reach over 130 psu during the dry season (November -June) and remain between 45-50 psu during the rainy season (July-October). The average water temperature is $25^{\circ} \mathrm{C}$ (Diouf 1996).

\section{Figure 1 here}

The Gambia River Estuary (Figure $1 \mathrm{~b}$ ) has a total catchment area of 78,000 $\mathrm{km}^{2}$ $\left(13^{\circ} 28^{\prime} \mathrm{N} ; 16^{\circ} 34^{\prime} \mathrm{W}-13^{\circ} 41^{\prime} \mathrm{N} ; 15^{\circ} 08^{\prime} \mathrm{W}\right)$. It originates in the Fouta-Djalon plateau and flows through Guinea. The estuary zone, considered in this study, has a total area of 654 
$\mathrm{km}^{2}$. Average depth varies from $3-15 \mathrm{~m}$. The average water temperature is $27^{\circ} \mathrm{C}$ and the average annual precipitation is $1,500 \mathrm{~mm}$. This ecosystem has a 'normal' decreasing down-to-upstream salinity gradient (Figure 1a). Maximum river flow ranges from 4.5$1,500 \mathrm{~m}^{3} \cdot \mathrm{s}^{-1}$. Water salinity at the mouth of the estuary varies between 38 and $45 \mathrm{psu}$ (Villanueva 2004).

\section{Ecosystem models}

The Ecopath software implements an ecosystem model based on a set of simultaneous linear equations for each entity considered. It assumes mass-balance, i.e., group production is equal to the sum of all predations, non-predatory loses and exports (Christensen et al. 2005). In order to minimize information loss and taxonomic biases, biological components are pooled according to similarities of species trophic properties (i.e., diets, predators and metabolism) and distribution (Yodzis and Winemiller 1999). Each trophic group has an energy balance expressed as:

$$
B_{i}\left(\frac{P}{B_{i}}\right)=\sum_{j=1}^{n} B_{j}\left(\frac{Q}{B_{i}}\right)-D C_{j i}+\left(B_{i}\right)\left(\frac{P}{B_{i}}\right)\left(1-E E_{i}\right)+E X_{i}
$$

where $B_{i}$ is the biomass of group $i, P / B_{i}$ is the production rate of $i$ equal to the total mortality coefficient $(Z)$ (Allen 1971); $Q / B_{i}$ is the relative consumption rate; $B_{j}$ is the biomass of the predating group $j ; D C_{j i}$, the proportion of the predated group $i$ in the diet of the predating group $j ; E E_{i}$ is the ecotrophic efficiency representing the part of the total production transferred to higher $T L s$ through predation or captured in the fisheries; $E X_{i}$ export or catch in fisheries of group $i$, assumed exploited in fisheries.

A total of 37 and 41 compartments were considered for the Sine-Saloum and Gambia models, respectively (Tables 1 and 2). The lower number of fish groups in SineSaloum is due to the absence of freshwater fishes caused by the inverse hypersalinity of the system following the Sahelian drought in the late 1960s as well as the lower species 
richness of euryhaline fishes. The input data were mainly primary data collected by (Simier et al. 2003), complemented by literature data (Albaret et al. 2004; Diouf 1996; Écoutin et al. 2005; Guillard 1998; Guillard et al. 2004; Healey et al. 1985; Laë et al. 2004; Panfili et al. 2004a; Panfili et al. 2004b; Simier et al. 2004; Simier et al. 2006). The choice of the study period was based on the availability and abundance of data for each ecosystem and on periods marked by considerable fishing and hydrologic variations: 1991 for Sine-Saloum and 2001 for Gambia. For trophic groups with several species, estimates were derived from properties of the dominant species. Biomasses were expressed and standardized as annual average in $\mathrm{t}^{\mathrm{k}} \mathrm{km}^{-2}$. Flows between compartments are given in $\mathrm{t} \cdot \mathrm{km}^{-2} \cdot \mathrm{yr}^{-1}$.

$B, P / B$ and $Q / B$ per functional group (Tables 1 and 2 ) were estimated using several empirical equations (De Mérona 1983; Froese and Palomares 2000; Gayanilo et al. 2002; Lévêque et al. 1977; Palomares and Pauly 1998; Pauly et al. 1993) using parameters obtained from several databases (Froese and Pauly 2014; N'Diaye et al. 2003; Simier et al. 2003) and information from the literature (Abarca-Arenas and Valero-Pacheco 1993; Albaret 1987; Arreguín-Sánchez et al. 1993; Bah et al. 2010; Chávez et al. 1993; FAO 1997; Guillard et al. 2004; Healey et al. 1985; Lhomme and Garcia 1984; Manickchand-Heileman et al. 1998; Mendy 2003; Mendy 2005; Njai 2000; Pagano and Saint-Jean 1994; Pauly 1982; Samb and Mendy 2003; Ziegler et al. 2011). DCs were initially summarized and compiled by Villanueva (2004). Complementary information were obtained from Diouf (1996), Ngouda (1997), Kone and Teugels (2003), Gning et al. (2008), Le Loc'h (2013) and Fishbase (Froese and Pauly 2014).

The Sine-Saloum catch data were from unpublished estimates provided by Dème (pers. comm., CRODT, Senegal) and complemented by artisanal catches (Simier et al. 2003). Here, high fish catches were recorded until the end of the 1970s. Reizer (1974) 
indicated annual catches of 18,500 to 25,900 tonnes. Others indicated twice these values, reaching up to 49,000 $\mathrm{t} \cdot \mathrm{yr}^{-1}$ (Ba et al. 2006; Bousso 1996; FAO 2006; Lesack 1986). A common observation, however, is that catches greatly declined by $50-80 \%\left(\sim 10,000 \mathrm{t} \cdot \mathrm{yr}^{-}\right.$

$\left.{ }^{1}\right)$ mainly due to the 20-year drought, which caused salinity levels 3-5 times higher (>100 psu upstream) than that of the adjacent sea, combined with a growing fishing effort.. A slight increase of annual fish catches has been observed recently (Niang 2009).

The fishery sector in Gambia still appears to operate at low-moderate levels (FAO 2006; Laë et al. 2004; Mbye 2005; United Nations 2014). Annual catches (fish, mollusks and shrimps) was estimated at 4,360 tonnes and the fishery is mainly artisanal (73-93\%). Mean annual shrimp catches during the early 1990s was estimated at 334 t, contributing $\$ 600,000$ per year to the economy of The Gambia. Despite 'normal', seasonal marine-freshwater inflow dynamics, it has one of the lowest annual fish yields compared to adjacent West African brackish waters (Lalèyè et al. 2007) and other tropical estuaries (Marten and Polovina 1982).

The Ecoranger routine of Ecopath was used to test for model sensitivity and to limit possible technical errors as it adjusts accordingly possible input parameters that can be modified depending on the data source and calculates the resulting impact. This is useful in refining less accurate data, common for most qualitative data on diet compositions (Christensen et al. 2005). Pedigree indices estimated through a quasiBayesian re-sampling technique were also implemented to quantify model uncertainties for reliable parameterization of Ecopath models (Kavanagh et al. 2004).

\section{Network analysis}

A. structural analyses

The Omnivory index $(O I)$ quantifies the variations of the TL of different preys consumed by a predator (Pauly et al. 1993). OIs near 0 indicate highly specialized 
predators. Group aggregations into discrete $T L s$ were carried out based on approach suggested by Ulanowicz (1995). This simplifies the food-web into discrete sums of input-output flows in one $T L$ to the next. This concept is a useful abstraction to organize energy transfers in ecosystems and overcome bias from varying species abundance when comparing ecosystem state and functioning.

\section{B. Network analyses}

Fishery gross efficiency $(G E)$ is computed as the ratio between the total catch (plus discards) and the total primary production $(T P P)$ in the system. The GE value is higher for systems with a fishery relying on low- $T L$ species. This index tends to increase with fisheries 'development' (Pauly et al. 1998). Total system throughput (TST) is defined as the sum of all flows in a system. It represents the 'size of the entire system in terms of flow' (Ulanowicz 1986). Total system biomass to the total system throughput ratio, B/TST, (Christensen 1995) is directly proportional to system maturity, where estimated value tends to be low during the ecosystem development phase and increases as a function of maturity. Energy is conserved through component energy stocking (Odum 1971; Ulanowicz 1986). The ratios of net primary production to total respiration $(P P / T R)$ and $T P P$ to production respiration $(T P P / P R)$ are system maturity indices (Christensen 1995; Odum 1969). Here, values close to 1 indicate an ecosystem approaching maturity.

System net primary production less total respiration $(N P P-T R)$ is another index of system maturity (Odum 1969) and should zero-out in a truly balanced ecosystem (Christensen 1995). System omnivory index (SOI) is computed as the average OI of all consumers weighted by the logarithm of each consumer food intake (Christensen et al. 2005). The Connectance index $(C I)$ for a given food web is the ratio of the number of actual links between groups to the number of theoretically possible links. Detrivory is included in the count, but the opposite links are disregarded. This index is correlated with 
system maturity because a trophic structure changes from linear to web-like as a system matures (Odum 1969).

Finn's cycling index $(F C I)$ is a quantitative importance of cycles in an ecosystem or the proportion of system recycled TST (Finn 1976). It is considered as an important indicator of ecosystem integrity through positive feedback (Allesina and Ulanowicz 2004) and can be used as stress (Ulanowicz 1986) or system maturity indicators (Vasconcellos et al. 1997). This is similar to predator cycling index (PCI), calculated by excluding the cycling through detritus. Disturbed systems are characterized by short-fast cycles while complex trophic structures have long and slow ones (Kay et al. 1989). Length of each cycle is quantified using Finn's mean path length, which accounts for the number of groups involved in a flow. Finn's straight-through path length (excluding detritus) is another ecosystem health indicator, wherein a low value translates a stressed ecosystem and a short food chain controlled by bottom-up forces (Christensen et al. 2005).

Macro-descriptors are typically applied for large and complex ecosystems whose aim is to present ecosystem growth and development. Ascendancy, $A$, (Ulanowicz 1997) and mutual information, I, (Hirata 1995) are examples of quantitative descriptors that differ from those used in classical food webs. Ascendancy is a measure of system growth (i.e., age, size) and development (i.e., organization) of network links, or simply, of ecosystem performance (Patrício et al. 2004; Ulanowicz 2000). The fraction of a system's capacity not considered as $A$ is considered as the systems overhead $(O)$, which is the energy in reserve of an ecosystem, useful in case of perturbations. The relative ascendancy $(A / C)$ is the fraction of possible organization that is actually realized and it is negatively correlated with maturity (Ulanowicz 1986).

\section{Results}




\section{Models sensitivity}

Basic parameterization results for the Sine-Saloum and Gambia models are shown in Tables 1 and 2, respectively. Pedigree sensitivity indices obtained were 0.81 and 0.78 for Sine-Saloum and Gambia models, respectively. Both values conform with the gauge of overall quality of an Ecopath model (Christensen et al. 2005). The Ecoranger routine was then used for each model to assess their viability. For SineSaloum, 165 acceptable runs out of 10,000 were obtained with a least sum of deviation equal to 10.08. A higher number of acceptable runs $(188 / 10,000)$ were obtained for Gambia with a least sum of deviation equal to 9.23 . These values indicated that both models are tightly fitted. The initial inputs-outputs based on field data were very close to the mean values generated by Ecoranger. Respiration to assimilation $(R / A)$, production to respiration $(P / R)$ ratios and estimated $E E$ s for all considered group are less than 1.

\section{Tables 1 and 2 here}

\section{Structural analyses}

Group TLs varied between 1.0 and 3.8 in Sine-Saloum and Gambia ecosystems. In the former, highest values corresponding to groups 1-3, 6-7 and 13 and where most fish groups $(72 \%)$ is at TLs 2-3 (Table 1). In Gambia, highest value corresponds to group 1 followed by groups $4-5$ and 12 and where most fish groups (82\%) is at TL3 (Table 2). Cumulative biomass of major fish groups is almost similar: Sine-Saloum $\left(9.13 \mathrm{tkm}^{-2}\right)$ and Gambia $\left(9.07 \mathrm{tkm}^{-2}\right)$. However, the fraction of fish groups belonging to TL3 is higher in the Gambia estuary (71\%) compared to that in Sine-Saloum (27\%).

Based on estuarine fish ecological categories (Figure 2I) suggested by Albaret (1994), most fish populations in terms of species occupying Sine-Saloum have strong marine water affinities (Figure 2II). The presence of an elevated number of strictly marine species is mainly due to the elevated salinity. Simier et al. (2004) identified 73 
species in their study, which is $40 \%$ lower than the value (123) indicated by Baran (2000). Species number and diversity vary, but were related to salinity stratification, with lowest values observed in upstream areas where hypersalinity of $>70 \mathrm{psu}$ was recorded. In general, hypersaline waters impose additional physiological challenges (i.e., greater osmotic and ionic stresses) on fishes which limit growth and production. Despite such extreme environments, fish assemblages have acclimatized to this ecosystem and actually characterized by a remarkably high biodiversity. Hypersaline areas, however, do not serve as nurseries (Vidy 2000) and are mainly inhabited by stunted estuarine fish species (e.g., Sarotherodon melanotheron). High fish species richness and biodiversity were also observed in other estuaries like in Casamance (Kantoussan et al. 2012), Mar Menor (Verdiell-Cubedo et al. 2013) and Rio Lagartos (Vega-Cendejas and Hernandez de Santillana 2004).

Figure 2 here

In Gambia, taxonomic richness is also elevated due to habitat diversity (Baran 2000). Seasonal inflows of fresh- and marine waters provide environment conditions to fish species with differing affinity to water salinity (Figure 2II). Contrary to SineSaloum, trophic structure is highly unstable as species display a strong seasonal variability. Seasonal cycle variations of phytoplankton and nutrient in estuaries cascade towards higher TLs in food web (Deegan and Garritt 1997). Variations in temperature and freshwater inputs would ultimately drive ecological changes and overall ecosystem structure and functioning.

OIs obtained are higher for most fish groups in Gambia than in Sine-Saloum (Tables 1 and 2). Lower OIs may be due to increased prey specialization of some fish groups depending on environmental conditions and availability of prey in each ecosystem. Higher group OIs in Gambia indicate fish groups with more diversified prey 
preferences as a response to seasonal environmental and biodiversity changes. It is interesting to note that seven functional groups in Gambia have OIs greater than 0.25 , compared to only four groups in Sine-Saloum. Among these are mobile epibenthos which consume plankton, benthos, crustaceans and organic materials.

Figure 3 here

Network analyses

Fish and crustacean biomasses and ecological production at TL2 is higher than at TL3 in Sine-Saloum. Biomass and catch are highest at TL3 in Gambia. The production at lower TLs are higher in Sine-Saloum compared to Gambia (Figure 3). TEs decline at higher TLs in both ecosystems (Figure 4), which is similar to observations in other tropical coastal ecosystems (Haputhantri et al. 2008; Van et al. 2010; Villanueva et al. 2006). TEs are higher in Sine-Saloum than in Gambia for TLs 2-3, but the trend reversed itself for $T L s$ 4-5, due to the difference of fish community roles in both ecosystems (Figure 2). The geometric mean TEs are 8.2 and $15.8 \%$ for Sine-Saloum and Gambia, respectively. The percentage of total flow originating from the detritus is similar for both estuaries: $43 \%$ in Sine-Saloum and $42 \%$ in Gambia.

\section{Figure 4 here}

Trophic interspecific responses for Sine-Saloum and Gambia are shown in figure

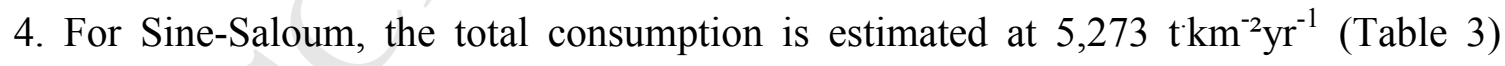
where $76 \%$ of flow from $T L s$ 1-2 originates from primary producers, whereas detritus contribute only $24 \%$, with a detrivory: herbivory ratio $(D: H)$ of $1: 3.1$. Most phytoplanktonic production is incorporated into the food web by macrobenthos. The $T E$ is highest at TL3 (9.0\%) and decreases at higher TLs. In Gambia, the total food consumption is lower and estimated at $1,317 \mathrm{t} \mathrm{km}^{-2} \mathrm{yr}^{-1}$ (Table 3). Energy transferred from $T L 1$ is accessed mainly from the primary production (58\%) by zooplankton and 
benthic organisms as compared to that coming from detritus (41\%) with a $D: H$ ratio of 1:1.4. TE rate is highest in $T L 2(19 \%)$ and decreases as $T L$ increases. The mean catch $T L$ is 2.59 in Sine-Saloum and is 3.10 in Gambia (Figure 3). Catch $G E$ is lower in SineSaloum (0.001) than in Gambia (0.005). TST for each ecosystem (Table 3) is higher in the former than the latter.

The highest flow back to detritus is observed from autotrophs $\left(8,118 \mathrm{tkm}^{-2} \mathrm{yr}^{-1}\right)$ in Sine-Saloum and from TL2 (376 tkmr- $\left.\mathrm{yr}^{-1}\right)$ in Gambia (Figure 4). Total ecosystem flow back to detritus in Sine-Saloum $\left(10,855 \mathrm{t} \mathrm{km}^{-2} \mathrm{yr}^{-1}\right)$ is 20 times higher than that observed in Gambia (530 tkmr $\left.\mathrm{km}^{-1}\right)$. Exploitation flows are highest in TL3 in both ecosystems (5.8 and $2.0 \mathrm{tkm}^{-2} \mathrm{yr}^{-1}$, respectively). The SOI value is slightly lower in Sine-Saloum (0.137) compared to Gambia (0.152). However, $C I$ in Sine-Saloum $(0.245)$ is almost twice that estimated for Gambia (0.192) which indicates a more complex, web-like feature of trophic structure in the former.

\section{Table 3 here}

In this study, Sine-Saloum is less mature than Gambia due to lower $T P P / P R$ and $B / T S T$ values. Considering other attributes of ecosystem maturity and stability such as $P P-T R$ and $P P / B$, values obtained for Sine-Saloum are higher than those in Gambia which indicate that the latter is reaching a mature stage sensu Odum (1969).

\section{Discussion}

\section{Estuarine biodiversity and species ecological roles}

Similarities in hypo-halobic and cosmopolitan species are mainly due to close biogeographic location of both systems. Dissimilarities in species occurrence and abundance may be due to specific hydrologic regimes occurring in each ecosystem (Baran 2000) and on their capacities of adaptation (Milton 2009). Both models show several common functional groups that occupy differing $T L$ in each ecosystem (Tables 1 
and 2) which may imply differences in ecological roles and ecosystem utilization. High biodiversity in estuaries can be attributed to various productive ecotones that can accommodate different biological populations (Cognetti and Maltagliati 2000). Resource utilization and ecological interactions are highly dependent on habitat heterogeneity and may explain deviation in trophic guilds and behaviors of similar taxonomic groups in different ecosystems (Villanueva et al. 2006).

Estuarine processes and lifecycles of estuarine organisms are strongly influenced by physiochemical, hydrological and seasonal variations, thus, making these ecosystems highly unstable and 'stressful'. Variations may either be naturally- or anthropogenicallyinduced, or both, leading to either positive or negative changes in biological assemblages. Seasonal marine and freshwater inflows are natural sources of variability and play significant roles in the various aspects of an organism's life cycle. Species usually have a higher capacity for adaptation due to exposure to constantly varying hydrologic conditions (Blaber 2002; James et al. 2013).

Sine-Saloum, where a severe and long-term hydroclimatic change occurred, is mainly inhabited by species of marine affinity (Figure 2b). Most hypersaline waters are associated with low biodiversity since, for most species, such extreme environments impose additional biological and physiological challenges (Brauner et al. 2013). Estuarine species of freshwater origin (i.e., Chrysichthys spp) have disappeared and the estuary is occupied by euryhaline fish assemblages (Baran 2000; Simier et al. 2004).

Taxonomic changes usually lead to structural and functional diversities (Villéger et al. 2010). Despite species diversity alterations, constant water hypersalinity conditions in Sine-Saloum seems to offer stabilized habitats/conditions for tolerant biological communities and has stabilized fish populations. High diversity, productivity and resilience of fish species to hypersalinity stress may also be driven by the presence of 
'bolongs' (Guèye et al. 2012), which are suitable places for refuge, limiting fish predation and niche competition (Vidy et al. 2004). In Gambia, these creeks function mainly as conduits that facilitate fish movements on and off the floodplain (Louca et al. 2008).

Fish biodiversity in Gambia is lower (89) compared to that observed in SineSaloum (Albaret et al. 2004). Overall species richness (Figure 2), however, is higher due to seasonal incursions of both marine and freshwater fish populations. These incursions, however, may be limited by dispersal opportunities depending on hydrodynamic conditions (Baran 2000). In Gambia, diversity and production are positively correlated where differences in distribution and eco-physiological characteristics increase efficiency of energy utilization. In Sine-Saloum, in contrast, a negative correlation can be observed due to the strong spatial zonation which may limit access and efficient use of available resources. High diversity can enhance ecosystem reliability through increase in redundant species per functional group. Some groups occupying a specific $T L$ maintain ecosystem functioning by compensating for temporary loss of other groups performing similar roles or occupying the same $T L$ (Naeem and Li 1997). This might explain higher SOI in Gambia despite seasonal temperature and fluvial inflow changes.

In both ecosystems, species belonging to three families Clupeidae (Ethmalosa fimbriata, Ilisha africana, Sardinella aurita and S. maderensis), Mugilidae (Liza spp and Mugil spp) and Cichlidae (S. melanotheron and Tilapia guineensis) are most abundant (Tables 1 and 2). In Sine-Saloum, these species appear to have developed adaptive mechanisms in order to persist under such stress. Their acclimatization is highly facilitated by their elevated capacity for osmoregulation, plasticity (Güner et al. 2005; Lorin-Nebel et al. 2012; Prunet and Bornancin 1989), which enables wide-range distributions (Guyonnet et al. 2003). 
Clupeids abundance and distribution are significantly different in these estuaries.

In Gambia, they are abundant along the mouth with relatively large seasonal oscillation, and decreasing abundance further upstream (Guillard et al. 2004). In Sine-Saloum, clupeids and cichlids are the most dominant fish species. S. maderensis has been observed to dominate areas with salinities $>60$ psu (Guillard 1998; Simier et al. 2004), showing that high water salinity does not limit their distribution.

The high versatility of $S$. melanotheron especially with regard to diet and habitat plasticity is well documented (Adité and Winemiller 1997; Gnohossou et al. 2013; Pauly et al. 1988), as well as its high tolerance of stress (Duponchelle and Panfili 1998; Duponchelle et al. 1998; Guèye et al. 2012; Panfili et al. 2004b). Tilapias are able to adapt and occupy hypersaline zones (>100 psu) in Sine-Saloum (Villanueva 2004). Guèye et al. (2012) reported threshold hypo- or hypersaline conditions beyond which stunted growth and precocious reproduction occur. Successful acclimatization to highly perturbed systems has been observed in Sakumo (Pauly 2002), Ébrié (Konan-Brou and Guiral 1994), Muni (Koranteng et al. 2000) and Toho-Todougba lagoons (Adité and Winemiller 1997). In Gambia, tilapias are present, though less abundant, and have a higher probability of occurrence along stenohaline and euryhaline zones (Guillard et al. 2004). Here, abundance and occurrence may be influenced by river discharges which increases availability of food (Amogu et al. 2010; Louca et al. 2008) similar to observations in South African estuaries (Whitfield and Harrison 2003). In both ecosystems studied, tilapias consume detritus and bacteria, especially in degraded habitats, as reported from other West African brackish waters (Gnohossou et al. 2013; Pauly 2002; Villanueva et al. 2006).

Network analyses 
Ecosystem functioning can be better viewed in terms of biomass fluxes between TLs. Predators and resource availability can cause direct changes of diversity from one $T L$ to the next (Nielsen 2001). This suggests that flow rates between predators and preys may vary as a function of limiting conditions or variables (Powers et al. 2003; Taylor et al. 2014). Higher biomasses were estimated for most functional groups in Gambia. Despite their higher abundance in Sine-Saloum, biomasses are low, as individual fish size are smaller than those inhabiting Gambia (Panfili et al. 2006). Fishes inhabiting hypersaline waters usually have a metabolic rate $40 \%$ lower than those found in seawater. Possible trade-offs with fish performance traits can include osmo-respiratory compromise in gill size, muscle fibre size, trait maintenance of energetic costs and gene expression modifications (Johnston et al. 2005; Lorin-Nebel et al. 2012; Sardella and Brauner 2007).

Estuaries have either a detritus- or phytoplankton-based food chain (Gearing et al. 1984; Maier et al. 2011). Primary producers and detritus are energy sources that play differing roles and significance in the diet of groups of higher TLs in these ecosystems. Results showed that phytoplankton is the key food source in both ecosystems (Figures 4). Elevated biomasses at TL1 in both ecosystems show its significant role in supporting species at higher TLs. Phytoplankton productivity is usually low in euryhaline waters as tidally imported seawaters have limited nutrient loading (Adams 1994). Productivity, however, is maintained in water salinities $<40$ psu (Schlacher and Wooldridge 1996). Lower utilization of primary production by zooplankton in Sine-Saloum may be due to the hypersalinity and temperature limiting effects on phytoplankton productivity and impose species composition changes. Microorganisms (halophilic algae and bacteria) can proliferate under such stress (Gunde-Cimerman et al. 2000). Deficiencies may also be complemented by productions from dense mangrove forests fueling grazing pathways similar to Orbetello (Brando et al. 2004) and Terminos lagoons (Rivera-Monroy et al. 
1998). Zooplankton density and species richness are lowest in hypersaline areas of Sine-

Saloum, as also reported from the Casamance (Debenay et al. 1989) and in Bardawil (Mageed 2006). Zooplankton communities (copepods, protozoa and mollusks) in these areas are strongly impacted and physiological constraints limit their abundance and distribution. Rotifer abundance seems low compared to other highly degraded West African brackish waters (Villanueva et al. 2006). In the Casamance estuary, zooplankton abundance and distribution decreased significantly in areas where salinity reached $70 \mathrm{psu}$ (Diouf and Diallo 1987) and impacted zooplanktivores distribution (Debenay et al. 1989). High primary productivity in estuaries may also be due to intense bacterial remineralization of organic matters and the continuous circulation of water and sediment nutrients which directly or indirectly regulate primary to secondary production (Sorokin et al. 1996), which is essentially the case in Gambia. In addition to nutrient loadings, seasonal river inflows lead to larger floodplains and diversified ecotones (Deegan and Garritt 1997; Louca et al. 2008). Freshwater inputs have positive effects on phytoplankton biomass and production (Adams 1994) in that fluvial hydrodynamics lead to vertical stratifications that retain system phytoplankton population. This process also releases the bulk of allochtonous or inorganic nutrients to estuarine primary producers.

In Sine-Saloum, poor utilization of $T L 1$ by $T L 2$ is indicated by the low phytoplankton transfer efficiency coupled with large flows back to detritus (Figures 4a). Primary link of $T L 1$ to $T L 2$ is mainly by epibenthos and herbivorous fish instead of zooplankton (Ngouda 1997). Zooplankton are rarely present in the diet of most planktivores, e.g., E. fimbriata. This visual-filtering clupeid has been observed in other estuaries as feeding mainly on zooplankton (Blay and Eyeson 1982). Stomach contents in Sine-Saloum contain large amounts of phytoplankton, especially in areas where salinity is $<50$ psu. Shrimps, crabs and some euryhaline fish tolerate such extreme conditions due to 
their efficient osmoregulation capacity and may participate in TL2 transfer to higher TLs (Deegan et al. 2010; Guerin and Stickle 1992; Lin et al. 2002). However, other less tolerant organisms may be inefficiently transferred to higher TLs due to hypersalinity limitations. The transfer efficiencies from TL2 may also be reduced by dense mangroves, used as refuge zones that limit predation.

In Gambia, zooplankton is the primary link of $T L 1$ to $T L 2$, as in Ebrié (Villanueva et al. 2006) and Huizache-Caimanero lagoons (Zetina-Rejón et al. 2003). Here, clupeids consume mainly zooplankton with a slight tendency of herbivory during the rainy season, which may explain lower flows back to the detritus (Figure 4b). Shift to a more phytoplankton- or detritus-based feeding behaviour may be an adaptive response to resource limitation. Substantial shift towards detrivory in other ecosystems coincide mainly to strong river run-offs (Charles-Dominique 1982; Gnohossou et al. 2013) and water salinities $>50$ psu (Villanueva 2004). Environmental degradation induced changes in species' diets have already been observed in other ecosystems such as the Terminos Lagoon (Villéger et al. 2010).

The importance of herbivory in both ecosystems is high, in accordance with Ngouda (1997), who demonstrated that even clupeid species such as the $S$. maderensis, E. fimbriata and I. africana consume large amount of phytoplankton. Clupeids in these ecosystems consume zooplankton in lower proportions compared to other West African brackish waters (Adité and Winemiller 1997; Charles-Dominique 1982).

Aside from physiological and biochemical mechanisms, fish tolerance to environmental stress is high for omnivores which are able to feed on a larger range of prey types and are important predators in highly unstable systems (Villanueva et al. 2006). Omnivory in a food web structure is of primary importance, as it can either contribute to ecosystem stability or instability (Vandermeer 2006). This can take the form 
of top-down control mechanism through strong predation, or via fishery (Bascompte et al. 2005) and may prevent species extinction by providing a wider range of prey choice to predators (Strong 1992). In other estuaries, trophic shifts from omnivory to grazing or detrivory have been observed as an adaptive response to severe resource limitations (Fox et al. 2009; Villanueva et al. 2006).

A greater interspecific resource partitioning seems to occur in Gambia than in Sine-Saloum. In Sine-Saloum, fish species with strong marine water affinities (Em and ME) have the highest $O I s$, while strictly estuarine and accessory fish species (Es and Ma) have more specialized feeding habit (Table 1). In Gambia, at least one fish functional group, usually with a high biomass, per ecological category has high $O I$ (Table 2) which may explain slightly higher SOI. Similar results were observed in Ebrié Lagoon (Villanueva et al. 2006) and Shoalhaven River (Taylor et al. 2014). Low CI coupled with a slightly elevated SOI may indicate an ecosystem less dependent on detritus as energy source (Heymans et al. 2004). Here, mangroves and terrestrial vegetation contribute to organic material productions complementing ecosystem phytoplankton production deficiencies (Bouillon et al. 2008).

Estuaries are very dynamic, and change and disturbance can be seen as natural features of these ecosystems (Bengtsson et al. 2000); thus, it seems paradoxal to describe them as stable systems (Mikkelson 1999). However, quantifying ecosystem changes and dynamics as a response to stress can be a gauge to evaluate ecosystem stability observed in mature systems (Odum 1969). Ecosystem interaction strength can be measured based on connectance (weighted number of nonzero entries in the flow matrix), such that more complex energetic flow network means higher ecosystem stability (Grimm et al. 1992). Length (absence or presence of predators) and strength (connectivity) of trophic links can also affect ecosystem stability. Higher $C I S$ and SOI estimated in Sine-Saloum 
indicate that it is more stable and has a higher resilience to stress than Gambia, despite similarly high biodiversity. Shorter, but stronger interaction strengths in Sine-Saloum may explain ecosystem stability despite strong environmental degradation coupled with overexploitation compared to other West African brackish water ecosystems (Villanueva et al. 2006). Ecosystem TLs is high along the estuary mouth due to high biological diversity which decreases exponentially in hypersaline areas. Villanueva (2004) indicated that food web structure in this estuary become shorter and less complex in areas where salinity values exceed 60 psu. In these hypersaline zones, very few species exist (Simier et al. 2004). Among fish species, only S. melanotheron is observed throughout the year. An ecosystem adaptive response under stress may lead to shorter, but tronger trophic interaction strengths among species. Simplification of trophic links (fewer predator-prey links) had been observed in highly stressed aquatic ecosystems (Moreau et al. 2001; Villanueva et al. 2006). Higher omnivory and shortening/strengthening of food chain lengths seem to increase in ecosystem stability (Long et al. 2011).

The $T P P / T R$ ratio in Sine-Saloum is high where total system respiration approaches its production, which is a common feature in highly stressed systems. According to Pagés et al. (1995), dissolved inorganic carbon concentrations decrease in hypersaline estuaries due to phytoplankton sedimentation, biological calcification or carbon loss from fish exportation leading to overall system high respiration rates. This is not, however, the case in Gambia. The estimated TST in Sine-Saloum $\left(27,938 \mathrm{t} \mathrm{km}^{-2} \mathrm{yr}^{-1}\right)$ is considerably higher than that estimated in Gambia $\left(2,585 \mathrm{tkm}^{-2} \mathrm{yr}^{-1}\right)$. TST estimates in this study are comparable to values obtained by Christensen and Pauly (1993) for coastal ecosystems, while lower than that obtained by Villanueva et al. (2006) in Lake Nokoué $\left(57,967 \mathrm{tkm}^{-2} \mathrm{yr}^{-1}\right)$ and Lin et al. (1999) in Chiku lagoon, China. 
System $A$ and TST can be used as an indicator of degradation in an ecosystem (Patrício et al. 2004). This is characterized by an increased value in $A$, as a function of elevated TST parallel to a decline in $I$ (Ulanowicz, 1986). In Sine-Saloum, an elevated $A$ is compensated by a low value of $I$ indicating higher degradation in the system, in contrast to Gambia, where $A$ and $I$ are low (Table 3).

Energy and matter recycling is considered as an important process in ecosystem functioning (Odum 1969) and is measured as FCI. According to Heymans and Baird (2000), value of this index is between $4-15 \%$ for coastal ecosystems. Estimated FCI value in Gambia is much higher than in Sine-Saloum (Table 3). It is, however, relatively low compared to that obtained by Villanueva et al. (2006) in other West African lagoons. Slightly higher value of Finn's straight-through path length (excluding detritus) in Sine-Saloum (2.82) suggests a shorter food chain perhaps due to shifting of diets of other groups towards detrivory, especially in hypersaline zones where primary production is strongly limited.

TEs from one $T L$ to the next are generally lower in Sine-Saloum compared to the Gambia estuary (Figures 4). A large bulk of energy from TL1 is not effectively transferred to higher TLS. According to Lindeman (1942), only $10 \%$ of net production from lower $T L$ is generally transferred to higher $T L$. Instead of being consumed, a significant amount of energy is lost due to non-predatory processes such as egestion, respiration and mortality. Most energy in Sine-Saloum is significantly lost either in respiration and flows back to detritus. In Gambia, on the other hand, energy losses per $T L$ transfer are proportionally lower. This may explain the higher $G E$ value calculated in Gambia compared to Sine-Saloum (Table 3). GEs are lower than the values obtained by Lin et al (1999) in Chiku lagoon. 
Apart from various industrialized and agricultural activities, over-fishing is responsible for a wide variety of impacts on fish communities, including modification of population composition and ecosystem adaptations to a changing environment due to stress conditions. In both estuaries, fisheries are mainly artisanal (Bousso 1996; Laë et al. 2004). Despite severe hydrologic changes due to climate change, annual catches are almost 4 times higher in Sine-Saloum $\left(12.057 \mathrm{tkm}^{2}\right)$ than in Gambia $\left(3.359 \mathrm{tkm}^{2}\right)$. Higher fish production in more degraded brackishwater ecosystems has already been observed by in Lake Nokoué where annual fish production can reach up to $102 \mathrm{t} \mathrm{km}^{2}$ ( $\sim 85 \%$ of this is the acadja-grown $S$. melanotheron) despite strong degradations (Villanueva et al. 2006).

In Sine-Saloum, catches are highest in TLs 2 and 3 estimated at 5.7 and $5.8 \mathrm{tkm}^{-2} \mathrm{yr}^{-}$ ${ }^{1}$, respectively (Figure 3a). E. fimbriata dominates by $80 \%$ the total landings followed by mullets (6\%). Other target species include mollusks $\left(2,601 \mathrm{t} \cdot \mathrm{yr}^{-1}\right)$ such as Arca senilis, murex, oysters and cymbium (Ba et al. 2006). In Gambia, catch is highest in TL3 (Figure 3b) mainly due to significant fish and shrimp artisanal fisheries by foreign/migrating fishermen from Senegal, Mali and Guinea. Recent estimates indicate that annual catch is 2,350 tonnes ( $77 \%$ fish and $23 \%$ shrimps). Fifty-five fish species were captured mainly using selective gears in this estuary but only $1 / 3$ of these accounted for $90 \%$ of the annual catch (Laë et al. 2004). Polydactylus quadrifilis and Arius spp. are the two main targeted fish species representing 26 and $20 \%$ of total fish landings, respectively.

Tropical estuaries and brackish ecosystems are constantly exposed to both longterm trends and rapid environmental changes. Biological organisms inhabiting these ecosystems have evolved under these changing environmental conditions while less tolerant species have become extinct (Baran 2000; Blaber 2002; Diouf 1996; Guèye et al. 2012). These ecosystems are often characterized by complex food webs and inhabiting 
biological communities have high eco-physiological capacities against extremely varying environmental conditions, in both space and time (Albaret et al. 2004; Villanueva et al. 2006). Levels of fish structure organizations in these ecosystems can be complex although frequent food web restructuration occurs due to seasonal variations, prey limitations and habitat modifications (Cloern and Jassby 2012; Fox et al. 2009; Winemiller and Jepsen 1998).

\section{Conclusions}

Global climate change and continued anthropogenic-driven environmental degradations contribute to biodiversity loss coupled with species extinctions (Sala et al. 2000; Stork 2009). Fishes and macroinvertebrates are very good environmental indicators to track environmental health and ecological changes as adaptive response to stress, especially in estuaries and lagoons (Elliot and Quintino 2007; Whitfield and Elliot 2002). Ecosystem-level indicators include several structural attributes such as food web complexities, energetic transfer efficiencies, species trophic links, system omnivory, maturity and interaction length just to enumerate some. Such food web properties have been proposed as determinants in ecosystem stability (Rambouts et al. 2013).

Debates on how biodiversity contributes to ecosystem stability exist in several literatures (Mooney 2002; Naeem 2002). Some indicate that high biodiversity ensures ecosystem stability through the multiplication of trophic roles by different species. In ecosystems where frequent seasonal species migrations or stress may occur, ecological or functional redundancy may ensure ecosystem stability through functional replacement of a particular species or community by another (Rosenfeld 2002). A negative effect of high biodiversity on ecosystem integrity can also be observed in other ecosystems. In highly unstable environments, biodiversity reduces variability in ecosystem productivity through 
compensatory effects where species abundance may increase as a response to a decrease of another (Naeem and Li 1997; Thébault and Loreau 2006).

Often, low species biodiversity can be observed in highly degraded ecosystems. This was not the case for the Sine-Saloum estuary where biodiversity remains elevated despite severe hydrodynamic changes. High biological diversity may largely contribute to ecosystem stability despite the regime shift as a response to climate change (Folke et al. 2004). System integrity may have been weakened due to extinctions and restructuration following freshwater inputs cutoff as other inhabiting species learned to adapt over time. Ecosystem stability seems maintained in highly stressed areas through further simplification of food web structure and increased recycling of organic matter. Coupled with strong anthropogenic degradation, Villanueva et al. (2006) reported when comparing two West African lagoons that ecosystem adaptation takes the form of a simplification of energetic links among biological communities under stressed conditions. In the Gambia estuary, on the other hand, biodiversity seems to promote production by maintaining ecosystem integrity through ecological/functional role redundancies of some groups occupying the same $T L$ (i.e., marine or estuarine fish predators by freshwater predators) against seasonal hydrodynamic and anthropogenic stresses coupled with high FCI.

Both ecosystems are phytoplankton-based as primary production showed a positive effect in supporting groups in higher TLs. Fish species in both estuaries showed wider niche diversifications and high structural organization of biological communities. Commercially important top fish predators were more sensitive to short-term pulsed events compared to lower level fish species. Most fish species in both ecosystems have opportunistic and omnivorous feeding habits that increase their survival and tolerance in such highly unstable environments. 
Both estuaries have complex food webs due mainly to numerous species utilizing these ecosystems for food, shelter and reproduction. Food web snapshots in this study indicate that both ecosystems are resilient to environmental stress and change, allowing maintenance of a functional ecosystem across seasonally-driven changes in environmental conditions and species assemblages and biomass. Biodiversity contributes by increasing trophic structure complexity in both estuaries but compared to SineSaloum, trophic links in Gambia seem more fragile due to seasonal trophic restructuration.

This study has also shown how regime shifts due to climate change and fisheries can impact ecosystem health and stability in a tropical estuary. A severe regime shift occurred in Sine-Saloum following the El Niño drought leading to marked shifts in trend, profoundly changing estuarine fauna and dynamics. Although the occurrence of freshwater forms completely disappeared, taxonomic richness and biodiversity in the estuary is as rich as in adjacent estuaries. Acclimatized species undergo drastic physiological and genetic adaptations (i.e., stunted sizes, higher osmoregulation, delayed reproduction, diet shifts) to survive and multiply. These, however, are not sufficient compensations for loss of freshwater biological diversity. At the ecosystem level, structure and internal ecological processes have evolved. Water hypersalinity in SineSaloum impose severe additional stress on biological assemblages leading to unfavorable system energetic flows. Results show that despite the regime shift, this estuary has evolved and dynamics have reached another level of system integrity. Based on ecosystem indicator results, Sine-Saloum seems slightly more stable mainly due to the 'long-term' abundance of highly adapted species that drive recovery processes under severe hydrodynamic perturbation. Due to short-term and seasonal marine-freshwater inflow shocks, Gambia undergoes seasonal food web restructuration that may impose 
decreasing resilience to recurring stress. Ecosystem ecological indicators considered in the study have already been used on other brackish water ecosystem health comparative and quality assessments

Anthropogenic stressors in West Africa are projected to increase due to exponential human population increase. This analysis illustrates the significance of sound estuarine structure description is crucial in understanding its dynamics and functioning. Understanding how the loss or reduction of a predator or prey, as well as, energetic links connecting them may affect ecosystem functioning is relevant especially on providing knowledge on the likely impact of anthropogenic related activities on ecosystem health. Such information is useful for refining future environmental management plans for estuarine biodiversity conservation.

\section{Acknowledgements}

I am grateful to colleagues who participated in the Réponses Adaptives des Poissons Project of Institut de Recherche pour le Développement (IRD) for providing data and information. I am also grateful to colleagues from CRODT in Dakar, Senegal and the Ministry of Fisheries and Water in Banjul, Gambia for relevant discussions and information on estuarine fisheries and for making this work possible. I am also grateful to two anonymous referees who have provided relevant insights and corrections that improved this work.

\section{References}

Abarca-Arenas, L.G., and E. Valero-Pacheco. 1993. Towards a trophic model of Tamiahua, a coastal lagoon in Mexico. Makati: ICLARM.

Adams, J.B. 1994. The importance of freshwater to the survival of estuarine plants. Ph.D. Thesis, University of Port Elizabeth. 
Adité, A., and K.O. Winemiller. 1997. Trophic ecology and ecomorphology of fish assemblages in coastal lakes of Benin, West Africa. Ecoscience 4: 6-23.

Albaret, J.-J. 1987. Le peuplements de poissons de la Casamance (Sénégal) en période de sécheresse. Revue d'Hydrobiologie Tropicale 20: 291-310.

Albaret, J.-J. 1994. Les poissons: Biologie et peuplements. In Environnement et ressources aquatiques de Côte d'Ivoire. Tome II - Les milieux lagunaires, ed. J.R. Durand, P. dufour, D. Guiral and S.G.F. Zabi, 239-273. Paris: ORSTOM.

Albaret, J.-J., M. Simier, F.S. Darboe, J.-M. Écoutin, J. Raffray, and L. Tito de Morais. 2004. Fish diversity and distribution in the Gambia Estuary, West Africa, in relation to environmental variables. Aquatic Living Resources 17: 35-46.

Allen, K.R. 1971. Relation between production and biomass. Journal of the Fisheries Research Board of Canada 28: 1573-1581.

Allesina, S., and R.E. Ulanowicz. 2004. Cycling in ecological networks: Finn's index revisited. Computational Biology and Chemistry 28: 227-233.

Alongi, D.M. 2008. Mangrove forests: Resilience, protection from tsunamis, and responses to global climate change. Estuarine, Coastal and Shelf Science 76: 113.

Amogu, O., L. Descroix, K.S. Yéro, E. Le Breton, I. Mamadou, A. Ali, T. Vischel, J.-C. Bader, I.B. Moussa, E. Gautier, S. Boubkraoui, and P. Belleudy. 2010. Incresing river flows in the Sahel? Water 2: 170-199.

Arreguín-Sánchez, F., J.C. Seijo, and E. Valero. 1993. An application of the Ecopath II to the north continental shelf ecosystem of Yucatan, Mexico. In Trophic box models of Aquatic Ecosystems, ed. V. Christensen and D. Pauly, 269-278. Makati: ICLARM. 
Ba, C.O., J.A. Bishop, M. Deme, H.D. Diadhiou, A.B. Dieng, O. Diop, P.A. Garzon, B. Guèye, M. Kebe, O.K. Ly, V. Ndiaye, C.M. Ndione, A. Sene, D. Thiam, and I.A. Wade. 2006. The economic value of wild resources in Seneegal: A preliinary evaluation of non-timber forest product, game and freshwater fisheries. Gland, Switzerland and Cambridge, U.K.: IUCN.

Bah, M., J. Tobey, and O. Drammeh. 2010. Artisanal shrimp (prawn) fishery value chain assessment, 36 pp: Coastal Resources Center, University of Rhode Island.

Balvanera, P., A.B. Pfisterer, N. Buchmann, J.-S. He, T. Nakashizuka, D. Raffaelli, and B. Schmid. 2006. Quantifying the evidence for biodiversity effects on ecosystem functioning and services. Ecology Letters 9: 1146-1156.

Baran, E. 2000. Biodiversity of estuarine fish faunas in West Africa. NAGA, The ICLARM Quarterly 23: 4-9.

Bascompte, J., C.J. Melián, and E. Sala. 2005. Interaction strength combinations and the overfishing of a marine food web. PNAS 102: 5443-5447.

Berlow, E.L., A.-M. Neutel, J.E. Cohen, P.C. De Ruiter, B. Ebenman, M. Emmerson, J.W. Fox, V.A.A. Jansen, J.I. Jones, G.D. Kokkoris, D.O. Logofet, A.J. Mckane, J.M. Montoya, and O. Petchey. 2004. Interaction strengths in food webs: issues and opportunities. Journal of Animical Ecology 73: 585-598.

Blaber, S.J.M. 2002. Fish in hot water: the challenges facing fish and fisheries research in tropical estuaries. Journal of Fish Biology 17: 143-162.

Blay, J.J., and K.N. Eyeson. 1982. Feeding activity and food habits if the shad, Ethmalosa fimbriata (Bowdich), in the coastal waters of Cape Coast, Ghana. Journal of Fish Biology 21: 403-410.

Bouillon, S., A.V. Borges, E. Castañeda-Moya, K. Diele, T. Dittmar, N.C. Duke, E. Kristensen, S.Y. Lee, C. Marchand, J.J. Middelburg, V.H. Rivera-Monroy, T.J. 
Smith III, and R.R. Twilley. 2008. Mangrove production and carbon sinks: A revision of global budget estimates. Global Biogeochemical Cycles 22: GB2013.

Bousso, T. 1996. Les pêche artisanale dans l'estuaire de Sine-Saloum (Sénégal): approches typologiques des systèmes d'exploitation., Université de Montpelier II.

Brando, V.E., R. Ceccarelli, S. Libralato, and G. Ravagnan. 2004. Assessment of environmental management effects in a shallow water basin using mass-balance models. Ecological Modelling 172: 213-232.

Brauner, C.J., R.J. Gonzalles, and J.M. Wilson. 2013. Extreme environments: Hypersaline, alkaline, and ion-poor waters. Fish Physiology 32: 435-476.

Charles-Dominique, E. 1982. Exposé synoptique des données biologiques sur l'ethmalose (Ethmalosa fimbriata S. Bowdich, 1825). Revue d'Hydrobiologie Tropicale 15: 373-397.

Chávez, E.A., M. Garduño, and F. Arreguín-Sánchez. 1993. Trophic dynamic structure of Celestun Lagoon, Southern Gulf of Mexico. In Trophic Models of Aquatic Ecosystems, ed. V. Christensen and D. Pauly, 186-192. Makati: ICLARM.

Christensen, V. 1995. Ecosystem maturity - towards quantification. Ecological Modelling 77: 3-32.

Christensen, V., and D. Pauly. 1993. Trophic models of Aquatic ecosystems, 390. Manila: ICLARM.

Christensen, V., C.J. Walters, and D. Pauly. 2005. Ecopath with Ecosim: a User's Guide., 154 p. Vancouver: University of British Columbia.

Christian, R.R., D. Baird, J. Luczkovich, J.C. Johnson, U.M. Scharler, and R.E. Ulanowicz. 2005. Role of network analysis in comparative ecosystem ecology of estuaries. In Aquatic Food Webs, ed. U.M.S. A. Belgrano, J. Dunne and R.E. Ulanowicz (Eds.), 25-40. Oxford: Oxford University Press. 
Cloern, J.E., S.Q. Foster, and A.E. Kleckner. 2013. Review: phytoplankton primary production in the world's estuarine-coastal ecosystems. Biogeosciences Discussions 10: 17725-177783.

Cloern, J.E., and A.D. Jassby. 2012. Drivers of change in estuarine-coastal ecosystems: Discoveries from four decades of study in San Francisco Bay. Reviews of Geophysics 50: doi: 10.1029/2012RG000397.

Cognetti, G., and F. Maltagliati. 2000. Biodiversity and adaptive mechanisms in brackish water fauna. Marine Pollution Bulletin 40: 7-14.

De Mérona, B. 1983. Modèle d'estimation rapide de la croissance des poissons: Application aux poissons d'eau douce d'Afrique. Revue d'Hydrobiologie Tropicale 16: 103-113.

Debenay, J.P., J. Pages, and P.S. Diouf. 1989. Ecological zonation of the hypersaline estuary of the Casamance River (Senegal): Foraminifera, zooplankton and abiotic variables. Hydrobiologia 174: 161-176.

Deegan, B.M., S. Lamontagne, K.T. Aldridge, and J.D. Brookes. 2010. Trophodynamics of the Coorong: Spatial variability in food web structure along a hypersaline coastal lagoon, 52 pp: CSIRO: Water for a healthy country National Research flagship.

Deegan, L.A., and R.H. Garritt. 1997. Evidence for spatial variability in estuarine food webs. Marine Ecology Progress Series 147: 31-47.

Diouf, P.S. 1996. Les peuplements de poissons des milieux estuariens de l'Afrique de l'Ouest: L'exemple de l'estuaire hyperhalin du Sine-Saloum, Université de Montpellier II Montpellier.

Diouf, P.S., and A. Diallo. 1987. Variations spatio-temporelles du zooplancton d'un estuaire hyperhalin: la Casamance. Revue d'Hydrobiologie Tropicale 20: 233-256. 
Duarte, C.M. 1995. Submerged aquatic vegetation in relation to different nutrient regimes. Ophelia 41: 87-112.

Duponchelle, F., and J. Panfili. 1998. Variations in age and size at maturity of female Nile tilapia, Oreochromis niloticus, populations from man-made lakes of Côte d'Ivoire. Environmental Biology of Fishes 52: 453-465.

Duponchelle, F., L. Pouyaud, and M. Legendre. 1998. Evidence of environmental effects on reproductive characteristics of Nile tilapia (Oreochromis niloticus) populations from man-made lakes or Ivory Coast. Aquatic Living Resources 11: 137-144.

Écoutin, J.-M., J.-J. Albaret, and S. Trape. 2005. Length-weight relationships for fish populations of a relatively undisturbed tropical estuary: The Gambia. Fisheries Research 72: 347-351.

Elliot, M., and V. Quintino. 2007. the estuarine quality paradox: Environment homeostasis and the difficulty of detecting anthropogenic stress in naturally stressed areas. Marine Pollution Bulletin 54: 640-645.

FAO. 1997. The status of inland fisheries in the Gambia, 5 p. Rome: FAO.

FAO. 2006. FishStat Plus database. Rome: Food and Agriculture Organization of the United Nations.

Ferreira, J.G., W.J. Wolff, T.C. Simas, and S.B. Bricker. 2005. Does biodiversity of estuarine phytoplankton depend on hydrology? Ecological Modelling 187: 513523.

Finn, J.T. 1976. Measures of ecosystem structure and function derived from analysis. Journal of Theoretical Biology 56: 363-380.

Folke, C., S. Carpenter, B. Walker, M. Scheffer, T. Elmqvist, L. Gunderson, and C.S. Holling. 2004. Regime shifts, resilience and biodiversity in ecosystem management. Annual Review of Ecology, Evolution and Systematics 35: 557-581. 
Fox, S.E., M. Teichberg, Y.S. Olsen, L. Heffner, and I. Valeila. 2009. Restructuring of benthic communities in eutrophic estuaries: Lower abundance of prey leads to trophic shifts from omnivory to grazing. Marine Ecology Progress Series 380: $43-$ 57.

Froese, R., and M.L. Palomares. 2000. Growth, natural mortality, length-weight relationship, maximum length and length-at-first-maturity of the coelacanth Latimeria chalumnae. Environmental Biology of Fishes 58: 45-52.

Froese, R., and D. Pauly. 2014. Fishbase.

Gayanilo, F.C.J., P. Sparre, and D. Pauly. 2002. The FAO-ICLARM Stock Assessment Tools (FiSAT II Ver. 1.0). Rome: FAO.

Gearing, J.N., P.J. Gearing, D.T. Rudnick, A.G. Requejo, and M.J. Hutchins. 1984. Isotopic variability of organic carbon in a phytoplankton-based temperate estuary. Geochimica et Cosmochimica Acta 48: 1089-1098.

Glaser, M. 2003. Interrelations between mangrove ecosystem, local economy and social sustainability in Caeté Estuary, North Brazil. Wetlands Ecology and Management 11: $265-272$.

Gning, N., G. Vidy, and O.T. Thiaw. 2008. Feeding ecology and ontogenic diet shifts of juvenile fish species in an inverse estuary: The Sine-Saloum, Senegal. Estuarine, Coastal and Shelf Science 76: 395-403.

Gnohossou, P., P. Lalèyè, P. Atachi, G. Magali, M.C. Villanueva, and J. Moreau. 2013. Temporal variations in the food habits of some fish species in Lake Nokoué, Benin. African Journal of Aquatic Science DOI: 10.2989/16085914.2013.792768.

Grimm, V., E. Schmidt, and C. Wissel. 1992. On the application of stability concepts in ecology. Ecological Modelling 63: 143-161. 
Guerin, J.L., and W.B. Stickle. 1992. Effects of salinity gradients on the tolerance and bioenergetics of juvenile blue crabs (Callinectes sapidus) from waters of different environmental salinities Marine Biology 114: 391-396.

Guèye, M., M. Tine, J. Kantoussan, P. Ndiaye, O.T. Thiaw, and J.-J. Albaret. 2012. Comparative analysis of reproductive traits in black-chinned tilapia females from various coastal marine, estuarine and freshwater ecosystems, PLoS ONE 7: e29464. doi:29410.21371/journal.pone.0029464.

Guillard, J. 1998. Daily migration cycles of fish populations in a tropical estuary (SineSaloum, Senegal) using a horizontal-directed split-beam transducer and multibeam sonar. Fisheries Research 35: 23-31.

Guillard, J., J.-J. Albaret, M. Simier, I. Sow, J. Raffray, and L. Tito de Morais. 2004. Spatio-temporal variability of fish assemblages in the Gambia Estuary (West Africa) observed by two vertical hydroacoustic methods: Moored and mobile sampling. Aquatic Living Resources 17: 47-55.

Gunde-Cimerman, N., P. Zalar, S. de Hoog, and A. Plemenitaš. 2000. Hypersaline waters in slaterns: Natural ecological niches for halophilic black yeasts. FEMS Microbiology - Ecology 32: 235-240.

Güner, Y., O. Özden, H. Cağirgan, M. Altunok, and V. Kizak. 2005. Effects of salinity on the osmoregulatory functions of the gills in Nile Tilapia (Oreochromis niloticus). Turkish Journal of Veterenary and Animal Science 29: 1259-1266.

Guyonnet, B., C. Aliaume, J.-J. Albaret, C. Casellas, A. Zerbi, G. Lassèrre, and T. Do Chi. 2003. Biology of Ethmalosa fimbriata (Bowdich) and fish diversity in the Ebrie Lagoon (Ivory Coast), a multipolluted environment. ICES Journal of Marine Science 60: 259-267. 
Haputhantri, S.S.K., M.C. Villanueva, and J. Moreau. 2008. Trophic interactions in the coastal ecosystem of Sri Lanka: An ECOPATH preliminary approach. Estuarine, Coastal and Shelf Science 76: 304-318.

Healey, M.J., R.A. Moll, and D. Page. 1985. Plankton assemblages of the Gambia River, West Africa (1983-1984). In International Programs Report No. 10, 106 p. Ann Arbor, Michigan: The University of Michigan.

Heymans, J., L. Shannon, and A. Jarre. 2004. Changes in the northern Benguela ecosystem over three decades: 1970s, 1980s and 1990s. Ecological Modelling 172: $175-195$.

Heymans, J.J., and D. Baird. 2000. Network analysis of the northern Benguela ecosystem by means of NETWRK and ECOPATH. Ecological Modelling 131: 97-119.

Hirata, H. 1995. Information theory and ecological networks. In Complex ecology: The part-whole relation in ecosystems, ed. B.C. Patten, S.E. Jørgensen and S.I. Auerbach, 623-642. New Jersey: Prentice Hall PTR.

Imperial, M.T., and T.M. Hennessey. 1996. An ecosystem-based approach to anaging estuaries: An assessment of the National Estuary Program. Coastal Management 24: $115-139$.

James, N.C., L. Van Niekerk, A.K. Whitfield, W.M. Potts, A. Götz, and A.W. Paterson. 2013. Effects of climate change on South African estuaries and associated fish species. Climate Research 57: 233-248.

Johnston, I.A., M. Abercromby, and O. Andersen. 2005. Loss of muscle fibres in a landlocked dwarf Atlantic salmon population. Biology Letters 1: 419-422.

Kantoussan, J., J.-M. Ecoutin, M. Simier, L. Tito de Morais, and R. Laë. 2012. Effects of salinity on fish assemblage structure: An evaluation based on taxonomicand 
functional approaches in the Casamance estuary (Senegal, West Africa). Estuarine, Coastal and Shelf Science: 1-11.

Kavanagh, P., N. Newlands, V. Christensen, and D. Pauly. 2004. Automated parameter optimization for Ecopath ecosystem models. Ecological Modelling 172: 141-149.

Kay, J.J., L.A. Graham, and R.E. Ulanowicz. 1989. A detailed guide to network analysis. In Network Analysis in Marine Ecology: Methods and Applications, ed. F. Wulff, J.G. Field and K.H. Mann, 15-60. Berlin: Springer-Verlag.

Kennedy, V.S. 1990. Anticipated effects of climmate change on estuarine and coastal fisheries. Fisheries 15: 16-24.

Konan-Brou, A.A., and D. Guiral. 1994. Available algal biomass in tropical brackish water artificial habitats.

Kone, T., and G.G. Teugels. 2003. Food habits of brackish water tilapia Sarotherodon melanotheron in riverine and lacustrine environments of a West African coastal basin. Hydrobiologia 490: 75-85.

Koranteng, K.A., P.K. Ofori-Danson, and M. Entsua-Mensah. 2000. Fish and fisheries of the Muni lagoon in Ghana, West Africa. Biodiversity and Conservation 9: 487499.

Laë, R., J.-M. Ecoutin, A. Mendy, J. Raffray, J.-Y. Weigel, O. Sadio, and O. Djobe. 2004. Effects of a targeted shrimp (Penaeus notialis) exploitation on fish catches in the Gambia estuary. Aquatic Living Resources 17: 75-85.

Lalèyè, P., M.C. Villanueva, M. Entsua-Mensah, and J. Moreau. 2007. A review of the aquatic living resources in the Gulf of Guinea lagoons, with particular emphasis on fisheries management. Journal of Afrotropical Zoology: 123-136.

Le Loc'h, F. 2013. Les réseaux trophiques de l'Aire Marine Protégée de Bamboung. In L'aire marine protégée communautaire de Bamboung (Sine saloum): synthèse 
2003-2011, ed. J.-M. Ecoutin, N. Béhagle, T. Brochier, J. Guillard, R. Laë, A. Lebourges-Dhaussy, F. Le Loc'h, J. Raffray, O. Sadio, M. Simier, I. Sow and L. Tito de Morais, 109-118. Dakar: IRD.

Lesack, L.F.W. 1986. Estimates of catch and potential yeild for the riverine artisanal fishery in the Gambia, West Africa. Journal of Fish Biology 28: 679-700.

Lévêque, C., J.-R. Durand, and J.-M. Écoutin. 1977. Relations entre le rapport P/B et la longévité des organismes. Cah. O.R.S.T.O.M., ser. Hydrobiol., 11: 17-31.

Lhomme, F., and S. Garcia. 1984. Biologie et exploitation de la crevette pénaeide au Sénégal, p. 111-144. In Penaeid shrimps: their biology and management, ed. J.A.a.B.J.R. Gulland, 308. Surrey, U. K.: Fishing News Books Ltd.

Lin, H.-J., K.-T. Shao, S.-R. Kuo, H.-L. Hsieh, S.-L. Wong, I.-M. Chen, W.-T. Lo, and J.-J. Hung. 1999. A Trophic Model of a Sandy Barrier Lagoon at Chiku in Southwestern Taiwan. Estuaries, Coastal and Shelf Science 48: 575-588.

Lin, H.C., Y.-C. Su, and S.-H. Su. 2002. A comparative study of osmoregulation in four fiddler crabs (Ocypodidae: Uca). Zoological Science 19: 643-650.

Lindeman, R.L. 1942. The trophic-dynamic aspect of ecology. Ecology 23: 399-418.

Long, Z.T., J.F. Bruno, and J.E. Duffy. 2011. Food chain length and omnivory determine the stability of a marine subtidal food web. Journal of Animal Ecology 80: 586594.

Lorin-Nebel, C., J.-C. Avare, N. Faivre, S. Wallon, G. Charmantier, and J.-D. Durand. 2012. Osmoregulatory strategies in natural populations of the black-chinned tilapia Sarotherodon melanotheron exposed to extreme salinities in West African estuaries. Journal of Comparative Physiology B 182: 771-780.

Lotze, H.K., H.S. Lenihan, B.J. Bourque, R.H. Bradbury, R.G. Cooke, M.C. Kay, S.M. Kidwell, M.X. Kirby, C.H. Peterson, and J.B.C. Jackson. 2006. Depletion, 
degradation, and recovery potential of estuaries and coastal seas. Science 312: 1806-1809.

Louca, V., S.W. Lindsay, S. Majambere, and M.C. Lucas. 2008. Fish community characteristics of the lower Gambia River floodplains: a study in the last major undisturbed West African river. Freshwater Biology: doi:10.1111/j.13652427.2008.02105.x.

Mageed, A.A.A. 2006. Spatio-temporal variations of zooplankton community in the hypersaline lagoon of Bardawil, North Sinai, Egypt. Egyptian Journal of Aquatic Research 32: 168-183.

Maier, G.O., J.D. Toft, and C.A. Simenstad. 2011. Variability in isotopic $\left(\delta^{13} \mathrm{C}, \delta^{15} \mathrm{~N}\right.$, $\delta^{34} \mathrm{~S}$ ) composition of organic matter contributing to detritus-based food webs of the Columbia River Estuary. Northwest Science 85: 41-54.

Manickchand-Heileman, S., F. Arreguín-Sánchez, A. Lara, and L.A. Soto. 1998. Energy flow and network analysis of Terminos Lagoon, SW Gulf of Mexico. Journal of Fish Biology 53: 179-197.

Marten, G.G., and J. Polovina. 1982. A comparative study of fish yield from various tropical ecosystems. In Theory and management of tropical multispecies fisheries ed. D. Pauly and G.I. Murphy, 255-285. Cronulia, Australia: ICLARM/CSIRO.

Mbye, E.M. 2005. Shrimp fishery of the Gambia: A case study of shrimp fishing gears, 23. Reykjavik, Iceland: the United Nations University.

Mendy, A.N. 2003. A trophic model of the Gambian Continental shelf system in 1986. In Fisheries Centre Research Reports, ed. M.L.D. Palomares and D. Pauly, 81-93.

Mendy, A.N. 2005. Trends in Gambian fisheries and fisheries statistics. In Pêcheries maritimes, écosystèmes et sociétés en Afrique de l'Ouest: Un demi-siècle de changement, ed. P. Chavance, M. Bâ and D. Gascuel, 70-78. 
Mikkelson, G.M. 1999. Methods and metaphors in community ecology: The problem of defining stability. Perspective on Science 5: 481-498.

Milton, D.A. 2009. Living in two worlds: Diadromous fishes, and factors affecting population connectivity between tropical rivers and coasts. In Ecological connectivity among tropical coastal ecosystems, ed. I. Nagelkerken, 325-355. Dordrecht Heidelberg London New York: Springer.

Mooney, H.A. 2002. The debate on the role of biodiversity in ecosystem functioning. In Biodiversity \& Ecosystem Functioning: synthesis and perspectives, ed. M. Loreau, S. Naeem and P. Inchausti, 12-17. New York: Oxgord University Press.

Moreau, J., M.C. Villanueva, U.S. Amarasinghe, and F. Schiemer. 2001. Trophic relationships and possible evolution of the production under various fisheries management strategies in a Sri Lankan Reservoir. In Proceedings of an International Workshop on Reservoir and Culture-based Fisheries: Biology and Management, 15-18 February 2000, ed. S.S. De Silva, 201-214. Bangkok: ACIAR.

N'Diaye, E., J.-M. Ecoutin, and M. Simier. 2003. Pêchart 2003: Logiciel de gestion de base de données des pêches artisanales en Afrique de l'Ouest, 71. Dakar: IRD.

Naeem, S. 2002. Biodiversity equals instability? Nature 416: 23-24.

Naeem, S., and S. Li. 1997. Biodiversity enhances ecosystem reliability. Nature 390: 507-508.

Ngouda, S. 1997. Contribution à l'étude qualitative du régime alimentaire de quelques poissons dans l'estuaire du Sine-Saloum (Sénégal). In Documents Scientifiques: Centre de Recherches Océanographiques de Dakar - Thiaroye. 
Niang, N.A. 2009. Dynamique socio-environnementale et développement local des regions côtières du Sénégal: L'exemple de la pêche artisanale, Université de Rouen.

Nielsen, K.J. 2001. Bottom-up and top-down forces in tide pools: test of a food chain model in an intertidal community. Ecological Monographs 72: 187-217.

Njai, S.E. 2000. Traditional fish processing and marketinng of the Gambia, 30. Banjul: Fisheries Department.

Odum, E.P. 1969. The strategy of ecosystem development. Science 164: 262-270.

Odum, E.P. 1971. Fundamentals of ecology. Philadelphia: W.B. Saunders Co.

Pagano, M., and L. Saint-Jean. 1994. Le zooplancton. In Environnement et ressources aquatiques de Côte d'Ivoire: Tome II - Les milieux lagunaires, ed. J.-R. Durand, P. Dufour, D. Guiral and S.G.F. Zabi, 155-188. Paris: ORSTOM.

Pagès, J., and J. Citeau. 1990. Rainfall and salinity of a Sahelian estuary between 1927 and 1987. Journal of Hydrology 113: 325-341.

Pagés, J., J. Lemoalle, and B. Fritz. 1995. Distribution of carbon in a tropical hypersaline estuary, the Casamance (Senegal, West Africa). Estuaries 18: 456-468.

Palomares, M.L.D., and D. Pauly. 1998. Predicting food consumption of fish populations as functions of mortality, food type, morphometrics, temperature and salinity. Mar. Freshwater Res. 49: 447-453.

Panfili, J., J.-D. Durand, A. Mbow, B. Guinand, K. Diop, J. Kantoussan, D. Thior, O. Thiaw, J.-J. Albaret, and R. Laë. 2004a. Influence of salinity on life-history traits of the bonga shad (Ethmalosa fimbriata, Pisces, Clupeidae): comparison between the Gambia and Saloum estuaries. Mar. Ecol. Prog. Ser. 270: 241-257.

Panfili, J., A. Mbow, J.-D. Durand, K. Diop, K. Diouf, D. Thior, P. Ndiaye, and R. Laë. 2004b. Influence of salinity on the life-history traits of the West African black- 
chinned tilapia (Sarotherodon melanotheron): comparison between the Gambia and Saloum estuaries. Aquatic Living Resources 17: 65-74.

Panfili, J., D. Thior, J.-M. Écoutin, P. Ndiaye, and J.-J. Albaret. 2006. Influence of salinity on the size at maturity for fish species reproducing in contrasting West African estuaries. Journal of Fish Biology 69: 95-113.

Patrício, J., R. Ulanowicz, M.A. Pardal, and J.C. Marques. 2004. Ascendency as an ecological indicator: a case study of estuarine pulse eutrophication. Estuarine, Coastal and Shelf Science 60: 23-35.

Pauly, D. 1982. A method to estimate the stock-recruitment relationship of shrimps. Transactions of the American Fisheries Society 111: 13-20.

Pauly, D. 2002. Spatial modelling of trophic interactions and fisheries impacts in coastal ecosystems: a case study of Sakumo Lagoon, Ghana. In The Gulf of Guinea large marine ecosystem: environmental forcing and sustainable development of marine resources., ed. J.M. McGlade, Cury, P., Koranteng, K. A., Hardman-Mountford, N. J., 289-296. Amsterdam: Elsevier Science B.V.

Pauly, D., V. Christensen, J. Dalsgaard, R. Fröese, and J. Torres, F. 1998. Fishing down marine food webs. Science 279: 860-863.

Pauly, D., J. Moreau, and M.L.D. Palomares. 1988. Detritus and energy consumption and conservation efficiency of Sarotherodon melanotheron (Cichlidae) in West African lagoon. Journal of Applied Ichthyology 4: 190-193.

Pauly, D., M. Soriano-Bartz, and M.L. Palomares. 1993. Improved construction, parametrization and interpretation of steady-state ecosystem models. In Trophic models of aquatic ecosystems, ed. V. Christensen and D. Pauly, 1-13. Manila, Philippines: ICLARM. 
Ponce Campus, G.E., M.S. Moran, A. Huete, Y. Zhang, C. Bresloff, T.E. Huxman, D. Eamus, D.D. Bosch, A.R. Buda, S.A. Gunter, T. Heartstill-Scalley, S.G. Kitchen, M.P. McClaran, W.H. cNab, D.S. Montoya, J.A. organ, D.P.C. Peters, E.J. Sadler, M.S. Seyfried, and P.J. Starks. 2013. Ecosystem resilience despite large-scale altered hydroclimatic conditiions. Nature 494: 349-353.

Powers, S.P., J.H. Grabowski, C.H. Peterson, and W.J. Lindberg. 2003. Estimating enhancement of fish production by offshore artificial reefs: uncertainty exhibited by divergent scenarios. Marine Ecology Progress Series 264: 265-277.

Prunet, P., and M. Bornancin. 1989. Physiology of salinity tolerance in tilapia: An update of basic and applied aspects. Aquatic Living Resources 2: 91-97.

Rambouts, I., G. Beaugrand, F. Artigas, J.-C. Dauvin, F. Gevaert, E. Goberville, D. Kopp, S. Lefebvre, C. Luczak, N. Spilmont, M. Travers-Trolet, M.C. Villanueva, and R.K. Kirby. 2013. Evaluating marine ecosystem health: Case studies of indicators using direct observations and modelling methods. Ecological Indicators 24: 353-365.

Reizer, C. 1974. Définition d'une politique d'aménagement des ressources halieutiques d'un écosystème complexe pr l'étude de son environnement abiotique, biotique et anthropique: Le fleuve Sénégal Moye, et Inférieur, Fondation Universitaire Luxembourgeoise.

Rivera-Monroy, V.H., C.J. Madden, J.W. Day Jr., R.R. Twilley, F. Vera-Herrera, and H. Alvarez-Guillén. 1998. Seasonal coupling of a tropical mangrove forest and an estuarine water column: Enhancement of aquatic primary productivity. Hydrobiologia 379: 41-53. 
Roessig, J.M., C.M. Woodley, J.J. Cech Jr., and L.J. Hansen. 2004. Effects of global climate change on marine and estuarine fishes and fisheries. Reviews in Fish Biology and Fisheries 14: 251-275.

Rosenfeld, J.S. 2002. Functional redundancy in ecology and conservation. Oïkos 98: 156162.

Sadovy, Y. 2001. The threat of fishing to highly fecund fishes. Journal of Fish Biology 59: $90-108$.

Sala, O.E., F.S. Chapin III, J.J. Armesto, E.L. Berlow, J. Bloomfield, R. Dirzo, E. HuberSanwald, L.F. Huenneke, R.B. Jackson, A. Kinzig, R. Leemans, D.M. Lodge, H.A. Mooney, M. Oesterheld, N.L. Poff, M.T. Sykes, B.H. Walker, M. Walker, and D.H. Wall. 2000. Global biodiversity scenarios for the year 2100. Science 287: $1770-1774$.

Samb, B., and A. Mendy. 2003. Dynamique du réseau trophique de l'écosystème sénégambien en 1990. In Trophic models of Northwest African Marine Ecosystems, ed. D. Pauly, M.L.D. Palomares and J.M. Vakily, 35-53. Dakar.

Sardella, B.A., and C.J. Brauner. 2007. The osmo-respiratory compromise in fish: The effects of physiological stae and the environment. In Fish respiration and environment, ed. M.N. Fernandes, F.T. Rantin, M.L. Glass and B.G. Kapoor, 147165. Enfield, N.H., U.S.A.: Science Publisher, Inc.

Schlacher, T.A., and T.H. Wooldridge. 1996. Ecological responses to reductio in freshwater supply and quality in South Africa's estuuaries: Lessons for manageent and conservation. Journal of Coastal Conservation 2: 115-130.

Simier, M., L. Blanc, C. Aliaume, P.S. Diouf, and J.-J. Albaret. 2004. Spatial and temporal structure of fish assemblages in an "inverse estuary" the Sine-Saloum system (Senegal). Estuarine, Coastal and Shelf Science 59: 69-86. 
Simier, M., J.-M. Écoutin, and E. Ndiaye. 2003. Pêchexp 2003 : Base de Données RAP, Volet Pêches Expérimentales : Notice descriptive. In Document Interne, 38 p. Dakar: Institut de Recherche pour le Développement.

Simier, M., C. Laurent, J.-M. Ecoutin, and J.-J. Albaret. 2006. The Gambia River estuary: a reference point for estuarine fish assemblages studies in West Africa. Estuarine, Coastal and Shelf Science 69: 615-628.

Sorokin, Y.I., P.Y. Sorokin, O. Giovanardi, and L. Dalla-Venezia. 1996. Study of the ecosystem of the lagoon of Venice, with emphasis on anthropogenic impact. Marine Ecology Progress Series 141: 247-261.

Stork, N.E. 2009. Re-assessing current extinction rates. Biodiversity and Conservation: doi:

Strong, D.R. 1992. Are trophic cascades all wet? Differentiation and donor-control in sceciose ecosystems. Ecology 73: 747-754.

Struyf, E., S. Van Damme, and P. Meire. 2004. Possible effects of climate change on estuarine nutrient fluxes: a case study in the highly nutrified Schelde estuary (Belgium, The Netherlands). Estuarine, Coastal and Shelf Science 60: 649-661.

Taylor, M.D., D.E. van der Meulen, M.C. Ives, C.T. Walsh, I.V. Reinfields, and C.A. Gray. 2014. Shock, stress or signal? Implications of freshwater flows for a toplevel estuarine predator. PLoS ONE 9: 995680. doi:95610.91371/journal.pone.0095680.

Thébault, E., and M. Loreau. 2006. The relationship between biodiversity and ecosystem functioning in food webs. Ecological Research 21: 17-25.

Ulanowicz, R. 1986. Growth and development: Ecosystem phenomelogy. New York: Springer Verlag. 
Ulanowicz, R.E. 1995. The part-whole relation in ecosystems. In Complex ecology, ed. B.C. Patten and S.E. Jørgensen, 549-560. New Jersey: Prentice-Hall, Englewood Cliffs.

Ulanowicz, R.E. 1997. Ecology, the ascendant perspective. New York: Columbia University Press.

Ulanowicz, R.E. 2000. Ascendancy: A measure of ecosystem performance. In Handbook of ecosystem theories and management, ed. S.E. Jørgensen and F. Müller, 303315. Boca Raton: Lewis Publishers.

United_Nations. 2014. The fisheries sector in the Gambia: Trade, value addition and social inclussiveness. In United Nations Conference on Trade and Development Enhanced Integrated Framework. New York and Geneva.

Van, M.T., N.T. Phuong, T.D. Dinh, M.C. Villanueva, and J. Moreau. 2010. A massbalance Ecopath model of coastal areas in the Mekong Delta, Vietnam. Asian Fisheries Science 23: 208-223.

Vandermeer, J. 2006. Omnivory and the stbility of food webs. Journal of Theoretical Biology 238: 497-504.

Vasconcellos, M., S. Mackinson, K. Sloman, and D. Pauly. 1997. The stability of trophic mass-balance models of marine ecosystems: a comparative analysis. Ecological Modelling 100: 125-134.

Vega-Cendejas, M.E., and M. Hernandez de Santillana. 2004. Fish community structure and dynamics in a coastal hypersaline lagoon: Rio Lagartos, Yucatan, Mexico. Estuarine, Coastal and Shelf Science 60: 285-299.

Verdiell-Cubedo, D., M. Torralva, A. Ruiz-Navarro, and F.J. Oliva-Paterna. 2013. Fish assemblages in different littoral habitat types of a hypersaline coastal lagoon (Mar Menor, Mediterranean Sea). Italian Journal of Zoology 80: 104-116. 
Vidy, G. 2000. Estuarine and mangrove systems and the nursery concept: which is which? The case of the Sine Saloum System (Senegal). Wetlands Ecology and Management 8: 37-51.

Vidy, G., F.S. Darboe, and E.M. Mbye. 2004. Juvenile fish assemblages in the creeks of the Gambia estuary. Aquatic Living Resources: 56-64.

Villanueva, M.C. 2004. Biodiversité et relations trophiques dans quelques milieux estuariens et lagunaires dans l'Afrique de l'Ouest: Adaptations aux pressions environnementales. Thèse de Doctorat, INP Toulouse.

Villanueva, M.C., P. Lalèyè, J.-J. Albaret, R. Laë, L. Tito de Morais, and J. Moreau. 2006. Comparative analysis of trophic structure and interactions of two tropical lagoons. Ecological Modelling 197: 461-477.

Villéger, S., J. Ramos Miranda, F.H. D., and D. Mouillot. 2010. Contrasting changes in taxonomic vs. functional diversity of tropical fish communities after habitat degradation. Ecological Applications 20: 1512-1522.

Welcomme, R.L. 2002. An evaluation of tropical brush and vegetation park fisheries. Fisheries Management and Ecology 9: 175-188.

Whitfield, A.K., G.C. Bate, J.B. Adams, P.D. Colwley, P.W. Froneman, P.T. Gama, N.A. Styrdom, S. Taljaard, A.K. Theron, J.K. Turpie, L. van Niekerk, and T.H. Wooldridge. 2012. A review of the ecology and management of temporarily open/closed estuaries in South Africa, with particular emphasis on river flow and mouth state as primary drivers of these systems. African Journal of Marine Science 34.

Whitfield, A.K., and M. Elliot. 2002. Fishes as indicators of environmental and ecological changes within estuaries: a review of progress and some suggestions for the future. Jour. Fish Biol. 61: 229-250. 
Whitfield, A.K., and T.D. Harrison. 2003. River flow and fish abundance in a South African estuary. Journal of Fish Biology 62: 1467-1472.

Winemiller, K.O., and D.B. Jepsen. 1998. Effects of seasonality and fish movements on tropical river food webs. Journal of Fish Biology 53 (Supp. A): 267-296.

Yodzis, P., and K.O. Winemiller. 1999. In search of operational trophospecieis in a tropical aquatic food web. Oikos 87: 327-340.

Zetina-Rejón, M.J., F. Arreguín-Sánchez, and E.A. Chávez. 2003. Trophic structure and flows of energy in the Huizache-Caimanero lagoon complex on the Pacific Coast of Mexico. Estuarine, Coastal and Shelf Science 57: 1-13.

Ziegler, F., A. Emanuelsson, J.L. Eichelsheim, A. Flycjö, V. Ndiaye, and M. Thrane. 2011. Extended life cycle assessment of southern pink shrimp products originating in Senegalese artisanal and industrial fisheries for export to Europe. Journal of Industrial Ecology 15: 527-538. 
Table 1. Basic inputs and estimated outputs (bold) of the Sine-Saloum estuary model. For fish groups with more than one species, a key species is considered and is indicated by $\left(^{*}\right)$. EC: Ecological category; TL: Trophic level; $B$ : biomass; $P / B$ : Production rate; $Q / B$ : Consumption rate; $Y$ : landings and OI: Omnivory index

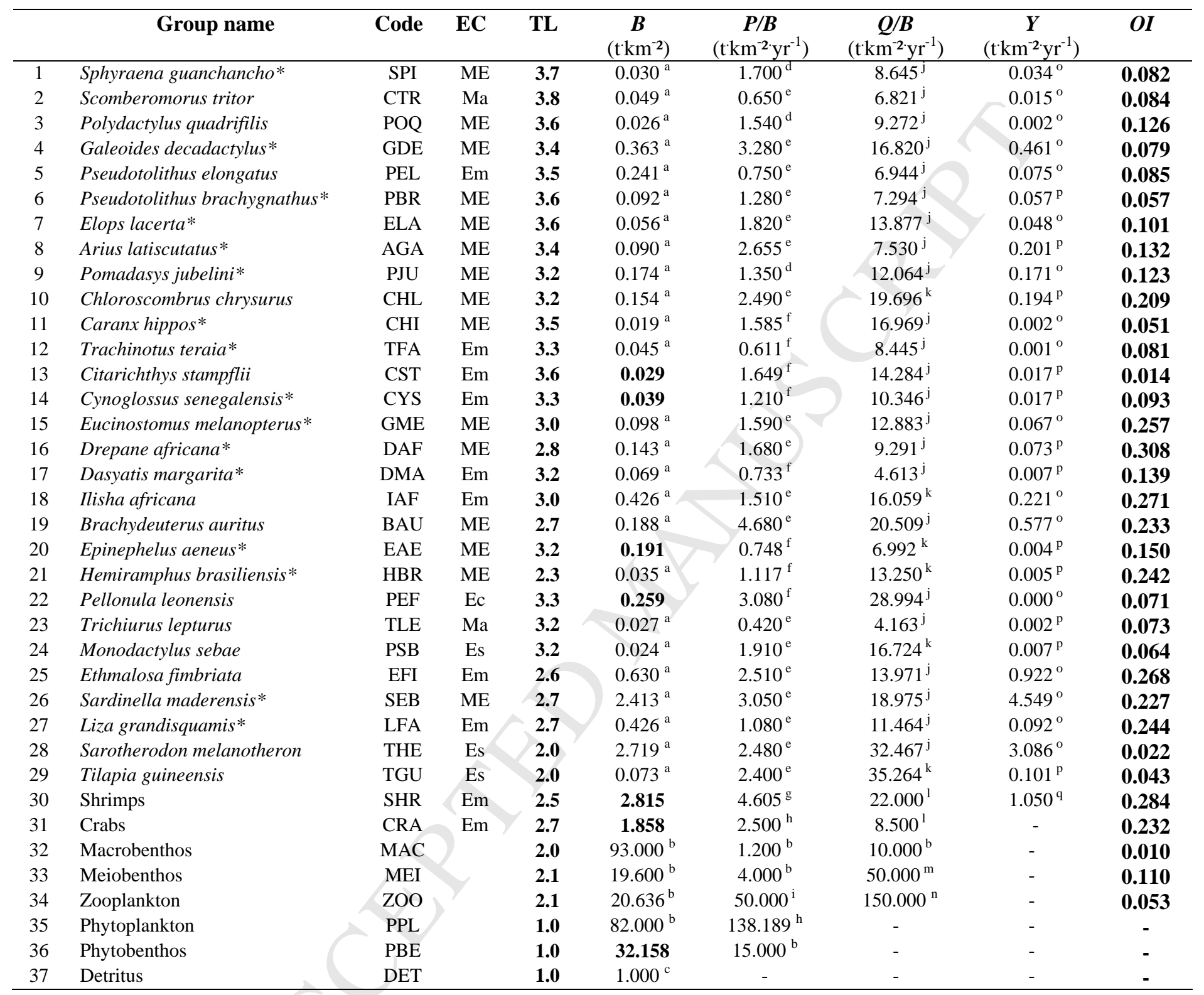

(a) Estimated from experimental fishing (Diouf 1996 ; Simier et al. 2003); (b) From Samb and Mendy (2003) ; (c) Based on a primary production multiple regression predictive model and euphotic zone depth (Pauly et al. 1993) ; (d) Estimated from Lévêque et al. (1977) ; (e) From Albaret (1987) and (Simier et al. 2003) using FiSAT (Gayanilo et al. 2002) ; (f) Estimated from de Merona (1983) and Fröese and Binohlan (2000) ; (g) Average P/B values obtained by Lhomme and Garcia (1984) of 4.2 and by Pauly (1982) of 5.01 ; (h) From Abaca-Arenas and Valero-Pacheco (1993); (i) From Pagano and Saint-Jean (1994); (j) Food consumption obtained using the predictive model of Palomares and Pauly (1998) from estimated aspect ratio values; (k) Obtained from the predictive model of Palomares and Pauly (1998) using aspect ratio values obtained from Fishbase (Fröese et Pauly 2014) ; (l) Q/B adopted from Arreguín-Sánchez et al. (1993) ; (m) From Chavez et al. (1993) ; (n) From Browder 1993 ; (o) Unpublished data from CRODT/ISRA; (p) Estimated as a function of biomass and fishing mortality coefficient (F), Y=B/F; and (q) From Bah et al (2010) and Ziegler et al. 2011. 
Table 2. Basic inputs and outputs (bold) of the Gambia estuary model. For fish groups with more than one species, a key species is considered and is indicated by $\left.{ }^{*}\right) . E C$ : Ecological category; TL: Trophic level; $B$ : biomass; $P / B$ : Production rate; $Q / B$ : Consumption rate; $Y$ : landings and $O I$ : Omnivory index.

\begin{tabular}{|c|c|c|c|c|c|c|c|c|c|}
\hline & Group name & Code & $\mathbf{C E}$ & TL & $\begin{array}{c}\boldsymbol{B} \\
\left(\mathrm{t} \cdot \mathrm{km}^{-2}\right)\end{array}$ & $\begin{array}{c}\boldsymbol{P} / \boldsymbol{B} \\
\left(\mathrm{t}^{\mathrm{km}}{ }^{-2} \mathrm{yr}^{-1}\right)\end{array}$ & 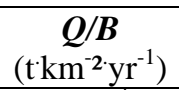 & $\begin{array}{c}\boldsymbol{Y} \\
\left(\mathrm{t}^{\mathrm{km}}{ }^{-2} \mathrm{yr}^{-1}\right)\end{array}$ & OI \\
\hline 1 & Sphyraena afra* & SPI & ME & 3.8 & 0.095 & $1.110^{\mathrm{d}}$ & $11.900^{\mathrm{i}}$ & $0.053^{\mathrm{k}}$ & 0.173 \\
\hline 2 & Polydactylus quadrifilis & POQ & $\mathrm{ME}$ & 3.3 & $1.509^{\mathrm{a}}$ & $0.850^{\mathrm{e}}$ & $4.519^{\mathrm{i}}$ & $0.688^{1}$ & 0.114 \\
\hline 3 & Galeoides decadactylus* & GDE & ME & 3.4 & $0.181^{\mathrm{a}}$ & $2.390^{\mathrm{e}}$ & $16.465^{\mathrm{i}}$ & $0.142^{1}$ & 0.062 \\
\hline 4 & Pseudotolithus elongatus & PEL & Em & 3.5 & $0.257^{\mathrm{a}}$ & $1.630^{\mathrm{e}}$ & $9.053^{\mathrm{i}}$ & $0.236^{1}$ & 0.128 \\
\hline 5 & Pseudotolithus senegalensis* & PSN & Ma & 3.6 & $0.405^{\mathrm{a}}$ & $0.680^{\mathrm{e}}$ & $4.495^{\mathrm{i}}$ & $0.134^{\mathrm{k}}$ & 0.081 \\
\hline 6 & Elops lacerta* & ELA & ME & 3.3 & 0.104 & $0.860^{\mathrm{e}}$ & $9.109^{\mathrm{i}}$ & $0.019^{\mathrm{k}}$ & 0.080 \\
\hline 7 & Arius latiscutatus* & AGA & ME & 3.4 & $1.613^{\mathrm{a}}$ & $1.140^{\mathrm{f}}$ & $10.117^{\mathrm{i}}$ & $0.534^{1}$ & 0.071 \\
\hline 8 & Pomadasys jubelini* & PJU & Em & 3.4 & 0.105 & $0.953^{f}$ & $10.409^{\mathrm{i}}$ & $0.069^{\mathrm{k}}$ & 0.034 \\
\hline 9 & Chloroscombrus chrysurus & CHL & ME & 3.1 & 0.005 & $3.950^{\mathrm{e}}$ & $25.291^{\mathrm{i}}$ & $0.005^{\mathrm{k}}$ & 0.175 \\
\hline 10 & Caranx hippos* & $\mathrm{CHI}$ & ME & 3.5 & $0.040^{\mathrm{a}}$ & $0.700^{\mathrm{e}}$ & $10.449^{\mathrm{i}}$ & $0.008^{1}$ & 0.081 \\
\hline 11 & Trachinotus teraia* & TFA & Em & 3.3 & $0.039^{\mathrm{a}}$ & $0.760^{\mathrm{e}}$ & $6.185^{i}$ & $0.012^{1}$ & 0.326 \\
\hline 12 & Citarichthys stampflii & CST & Em & 3.5 & 0.005 & $2.413^{\mathrm{f}}$ & $17.988^{\mathrm{i}}$ & $0.000^{\mathrm{k}}$ & 0.034 \\
\hline 13 & Cynoglossus senegalensis* & CYS & Em & 3.3 & $0.463^{\mathrm{a}}$ & $0.570^{\mathrm{e}}$ & $5.768^{\mathrm{i}}$ & $0.100^{1}$ & 0.155 \\
\hline 14 & Eucinostomus melanopterus* & GME & ME & 3.1 & 0.066 & $1.643^{f}$ & $15.621^{\mathrm{i}}$ & $0.001^{\mathrm{k}}$ & 0.155 \\
\hline 15 & Drepane africana* & DAF & ME & 2.8 & $0.042^{\mathrm{a}}$ & $1.170^{\mathrm{f}}$ & $7.880^{\mathrm{i}}$ & $0.016^{\mathrm{k}}$ & 0.384 \\
\hline 16 & Dasyatis margarita* & DMA & Em & 3.4 & $0.107^{\mathrm{a}}$ & $0.706^{f}$ & $7.122^{\mathrm{i}}$ & $0.022^{1}$ & 0.080 \\
\hline 17 & Ilisha Africana & IAF & Em & 3.1 & $0.032^{\mathrm{a}}$ & $3.400^{\mathrm{e}}$ & $18.436^{\mathrm{i}}$ & $0.067^{1}$ & 0.146 \\
\hline 18 & Brachydeuterus auritus & BAU & ME & 3.1 & 0.016 & $2.340^{f}$ & $19.684^{\mathrm{i}}$ & $0.001^{\mathrm{k}}$ & 0.020 \\
\hline 19 & Hemichromis fasciatus* & EAE & Ec & 3.3 & $0.212^{\mathrm{a}}$ & $0.800^{\mathrm{f}}$ & $8.668^{\mathrm{i}}$ & $0.058^{1}$ & 0.072 \\
\hline 20 & Schilbe intermedius* & SIN & $\mathrm{Ce}$ & 3.1 & 0.003 & $1.690^{\mathrm{f}}$ & $16.093^{i}$ & $0.000^{\mathrm{k}}$ & 0.199 \\
\hline 21 & Strongylura senegalensis* & BES & Em & 3.2 & 0.005 & $0.725^{\mathrm{f}}$ & $12.307^{\mathrm{i}}$ & $0.000^{\mathrm{k}}$ & 0.117 \\
\hline 22 & Hydrocynus forskalii* & HOD & Co & 3.3 & $0.381^{\mathrm{a}}$ & $0.737^{\mathrm{e}}$ & $7.824^{\mathrm{i}}$ & $0.008^{1}$ & 0.175 \\
\hline 23 & Pellonula leonensis & PEF & Ec & 3.2 & 0.010 & $2.716^{\mathrm{f}}$ & $29.505^{i}$ & $0.000^{\mathrm{k}}$ & 0.066 \\
\hline 24 & Chrysichthys auritus* & CNI & Ec & 3.3 & $0.203^{\mathrm{a}}$ & $0.730^{\mathrm{e}}$ & $6.548^{\mathrm{i}}$ & $0.041^{\mathrm{k}}$ & 0.022 \\
\hline 25 & Trichiurus lepturus & TLE & $\mathrm{Ma}$ & 3.2 & 0.079 & $0.440^{\mathrm{f}}$ & $4.368^{\mathrm{i}}$ & $0.003^{k}$ & 0.288 \\
\hline 26 & Synodontis gambiensis * & SYG & $\mathrm{Ce}$ & 2.8 & 0.007 & $4.170^{\mathrm{f}}$ & $21.508^{\mathrm{i}}$ & $0.003^{\mathrm{k}}$ & 0.314 \\
\hline 27 & Monodactylus sebae & PSB & Es & 3.1 & $0.079^{\mathrm{a}}$ & $1.660^{\mathrm{e}}$ & $15.348^{\mathrm{i}}$ & $0.011^{\mathrm{k}}$ & 0.027 \\
\hline 28 & Ethmalosa fimbriata & EFI & Em & 2.7 & 1.094 & $1.400^{\mathrm{e}}$ & $9.063^{\mathrm{i}}$ & $0.106^{\mathrm{k}}$ & 0.281 \\
\hline 29 & Sardinella maderensis* & SEB & ME & 3.0 & 0.268 & $5.260^{f}$ & $27.707^{\mathrm{i}}$ & $0.001^{\mathrm{k}}$ & 0.123 \\
\hline 30 & Liza grandisquamis* & LGR & Em & 2.4 & $0.591^{\mathrm{a}}$ & $1.660^{\mathrm{f}}$ & $14.523^{\mathrm{i}}$ & $0.152^{1}$ & 0.251 \\
\hline 31 & Tylochromis jentinki & TJE & Es & 3.0 & 0.130 & $1.738^{\mathrm{f}}$ & $11.724^{\mathrm{i}}$ & $0.000^{\mathrm{k}}$ & 0.300 \\
\hline 32 & Sarotherodon melanotheron & THE & Es & 2.1 & 0.640 & $1.740^{\mathrm{e}}$ & $22.616^{\mathrm{i}}$ & $0.042^{\mathrm{k}}$ & 0.080 \\
\hline 33 & Tilapia guineensis & TGU & Es & 2.0 & 0.284 & $1.902^{\mathrm{e}}$ & $43.794^{\mathrm{i}}$ & $0.001^{\mathrm{k}}$ & 0.024 \\
\hline 34 & Shrimps & SHR & Es & 2.6 & 1.436 & $3.000^{\mathrm{b}}$ & $22.000^{b}$ & $0.821^{\mathrm{m}}$ & 0.373 \\
\hline 35 & Crabs & CRA & Es & 2.8 & 5.794 & $2.000^{\mathrm{b}}$ & $8.000^{j}$ & $0.006^{\mathrm{k}}$ & 0.404 \\
\hline 36 & Macrobenthos & MAC & & 2.4 & 9.016 & $5.000^{\mathrm{b}}$ & $20.000^{b}$ & - & 0.239 \\
\hline 37 & Meiobenthos & MEI & & 2.0 & 6.073 & $10.383^{g}$ & $48.763^{\mathrm{i}}$ & - & 0.001 \\
\hline 38 & Zooplankton & $\mathrm{ZOO}$ & & 2.1 & $5.500^{\mathrm{b}}$ & $30.000^{\mathrm{g}}$ & $120.000^{\mathrm{b}}$ & - & 0.111 \\
\hline 39 & Phytoplankton & PPL & & 1.0 & $6.000^{c}$ & $96.853^{h}$ & - & - & - \\
\hline 40 & Phytobenthos & PBE & & 1.0 & $10.500^{b}$ & $15.000^{b}$ & - & - & - \\
\hline 41 & Detritus & DET & & 1.0 & $1.832^{\mathrm{C}}$ & - & - & - & - \\
\hline
\end{tabular}

(a) Estimated from Guillard et al. 2004 and Mendy 2005 ; (b) From Mendy (2003) ; (c) Based on a primary production multiple regression predictive model and euphotic zone depth (Pauly et al. 1993) ; (d) From Ndiaye et al. 2003 using predictive model of Fröese and Binohlan (2000); (e) Value estimated from Ndiaye et al. 2003 using FiSAT (Gayanilo et al. 2002) ; (f) Value from Simier et al. 2003 ; (g) Manickchand-Heileman et al. (1998); (h) Healey et al. (1985); (i) Obtained using the predictive model of Palomares and Pauly (1998) from estimated aspect ratio values ; (j) ArreguínSánchez et al. (1993) ; (k) FAO 1997 and Mendy 2005 ; (l) FAO 1997 and Njai 2000 complemented with unpublished data; and (m) From Laë et al. (2004) and Mbye 2005. 
Table 3. Summary statistics and network flow indices of the two ecosystems considered.

\begin{tabular}{|c|c|c|}
\hline \multirow[t]{2}{*}{ Parameter } & \multicolumn{2}{|c|}{ Value } \\
\hline & Sine-Saloum & Gambia \\
\hline \multicolumn{3}{|l|}{ Ecosystem theory indices } \\
\hline Sum of all consumption $\left(\mathrm{t}^{\mathrm{k}} \mathrm{km}^{-2} \mathrm{yr}^{-1}\right)$ & 5273.320 & 1317.033 \\
\hline Sum of all exports $\left(\mathrm{t}^{\mathrm{km}} \mathrm{km}^{-2} \mathrm{yr}^{-1}\right)$ & 9677.043 & 81.547 \\
\hline Sum of all respiratory flows $\left(\mathrm{tkm}^{-2} \mathrm{yr}^{-1}\right)$ & 2138.531 & 657.071 \\
\hline Sum of all flows into detritus $\left(\mathrm{t}^{\mathrm{km}}{ }^{-2} \mathrm{yr}^{-1}\right)$ & 10855.340 & 529.494 \\
\hline Total system throughput (TST. $\mathrm{tkm}^{-2} \mathrm{yr}^{-1}$ ) & 27938.000 & 2585.000 \\
\hline Sum of all production $\left(\mathrm{t} \mathrm{km}^{-2} \mathrm{yr}^{-1}\right)$ & 13074.000 & 1036.000 \\
\hline Mean trophic level of the catch & 2.59 & 3.10 \\
\hline Gross efficiency (GE. catch/net p.p.) & 0.001020 & 0.004548 \\
\hline Calculated total net primary production $\left(\mathrm{tkm}^{-2} \mathrm{yr}^{-1}\right)$ & 11815.570 & 658.511 \\
\hline Total primary production/total respiration (TPP/TR) & 5.525 & 1.124 \\
\hline Net system production (PP-TR. $\mathrm{tkm}^{-2} \mathrm{yr}^{-1}$ ) & 9677.043 & 81.547 \\
\hline Total primary production/total biomass (PP/B. $\mathrm{yr}^{-1}$ ) & 45.278 & 13.834 \\
\hline Total biomass/total system throughput ( $B$-TST. yr $^{-1}$ ) & 0.009 & 0.021 \\
\hline Total biomass (excluding detritus) ( $\left(\mathrm{km}^{-2}\right)$ & 260.957 & 53.390 \\
\hline Total catches $\left(\mathrm{t}^{\mathrm{km}}{ }^{-2} \mathrm{yr}^{-1}\right)$ & 12.057 & 3.359 \\
\hline Connectance Index $(C I)$ & 0.245 & 0.192 \\
\hline System Omnivory Index (SOI) & 0.137 & 0.152 \\
\hline \multicolumn{3}{|l|}{ Cycling indices } \\
\hline Throughput cycled excluding detritus $\left(\mathrm{t}^{\mathrm{km}} \mathrm{km}^{-2} \mathrm{yr}^{-1}\right)$ & 164.65 & 66.32 \\
\hline Throughput cycled (including detritus) $\left(\mathrm{t}^{\mathrm{km}}{ }^{-2} \mathrm{yr}^{-1}\right)$ & 22.01 & 17.12 \\
\hline Finn’s cycling index (FCI. \%) & 2.68 & 14.99 \\
\hline Predatory cycling index (PCI. \%) & 2.64 & 4.35 \\
\hline Finn's mean path length & 2.368 & 3.500 \\
\hline Finn's straight-through path length (excluding detritus) & 2.819 & 2.210 \\
\hline Finn's straight-through path length (including detritus) & 2.301 & 2.975 \\
\hline \multicolumn{3}{|l|}{ Information indices } \\
\hline Ascendancy (A. flowbits) & 30892.50 & 2730.70 \\
\hline Overhead (Ø. flowbits) & 51491.4 & 9091.7 \\
\hline Capacity (C. flowbits) & 82383.9 & 11822.4 \\
\hline Information $(I)$ & 1.106 & 1.056 \\
\hline$A / C$ & 0.375 & 0.231 \\
\hline
\end{tabular}


Legends of figures:

Figure 1. The Sine-Saloum estuary in Senegal (A, above) and the Gambia River-Estuary in Gambia (B, below). Graphs show monthly salinity variations at different zones of each estuary. Values encircled are maximum values recorded for each zone. Salinity gradient from the mouth to the upstream area of each estuary (b).

Figure 2. (I) Fish population ecological categories in Estuarine-Lagoon Systems (ELS). The population abundance is noted as: * rare, $* *$ abundant or *** very abundant; $\mathrm{R}$ indicates reproduction in brackishwaters; $\mathrm{D}$ indicates distribution in ELS: V-vast, L-limited, S-seasonally or P-permanent and E euryhalinity (modified from Albaret 1994). (II) Species abundance per ecological category in the two ecosystems considered (Source:

Villanueva 2004).

Figure 3. Detailed trophic structure of biomass $\left(\mathrm{t} \mathrm{km}^{-2}\right.$, left $)$ and ecologic production $\left(\mathrm{t} \mathrm{km}^{-2} \mathrm{yr}^{-1}\right.$, right $)$, of fish groups as summarized using Ecopath: (A) Sine-Saloum and (B) Gambia.

Figure 4. Simplified trophic flow models of Sine-Saloum (a) and Gambia (b) estuaries showing discrete trophic levels. Detritus (part of TL I) has been separated to show its significance as energy source in each ecosystem. Percentage (\%) values indicate trophic efficiencies per trophic level. Numbers on arrows indicate flow of energy expressed in $\mathrm{t}^{\mathrm{km}} \mathrm{yr}^{-2} \cdot$ 


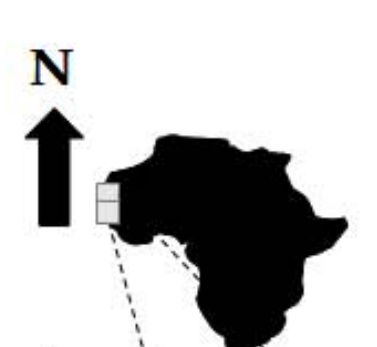

A.
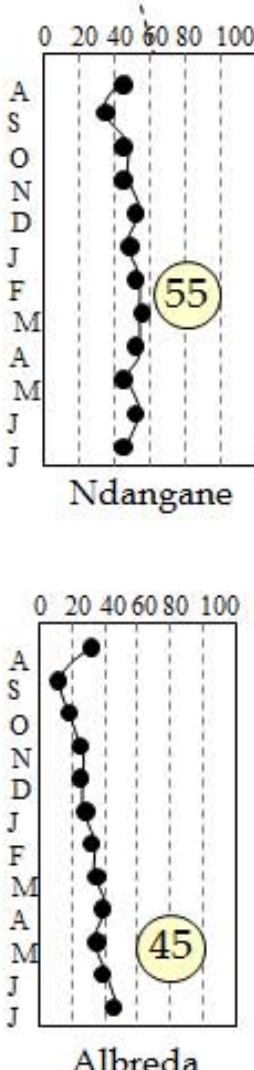

Albreda

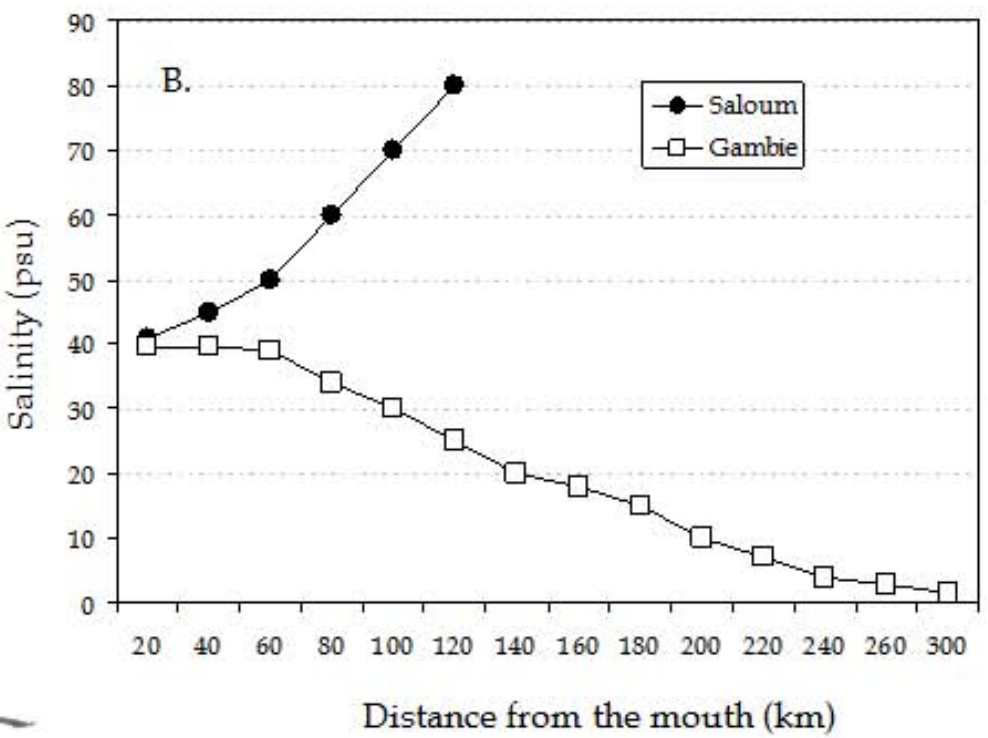

SINE-SALOUM

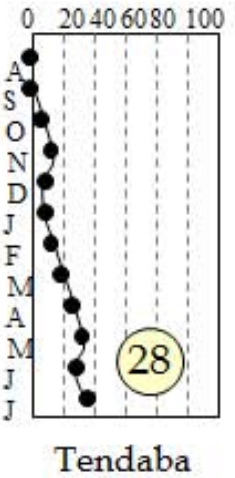

Figure 1

Villanueva 
I.

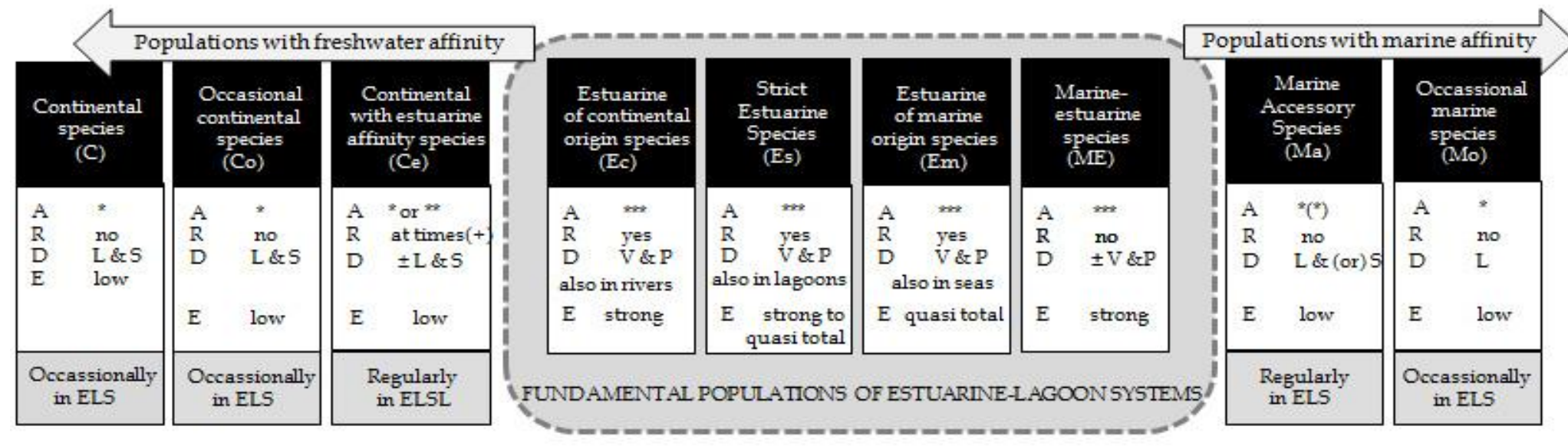

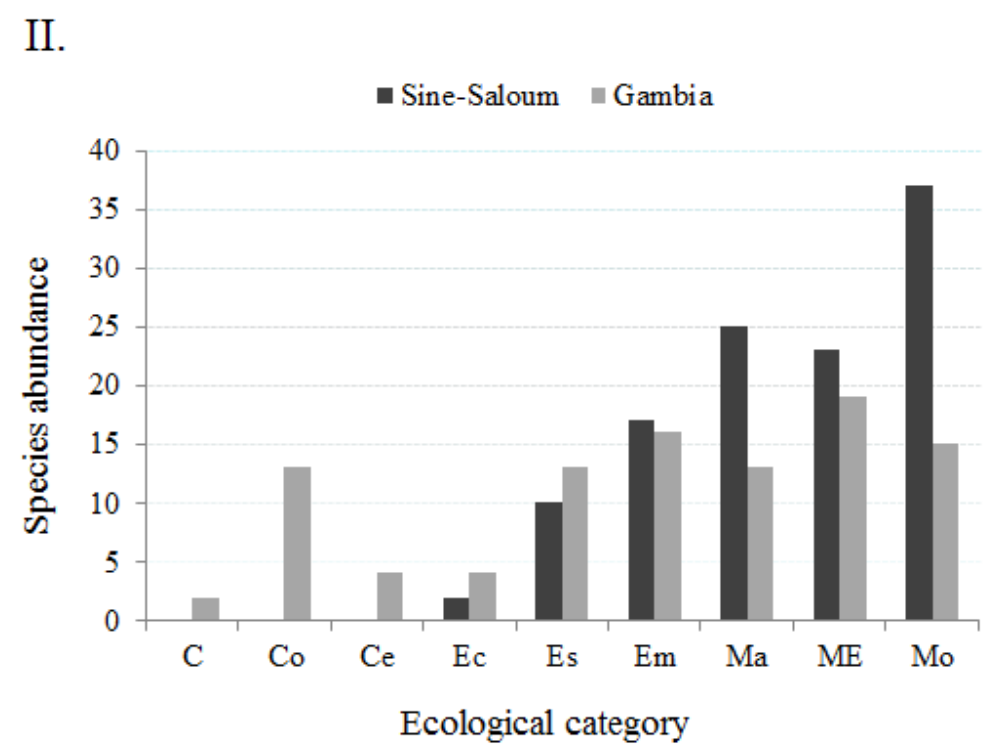

Figure 2

Villanueva 


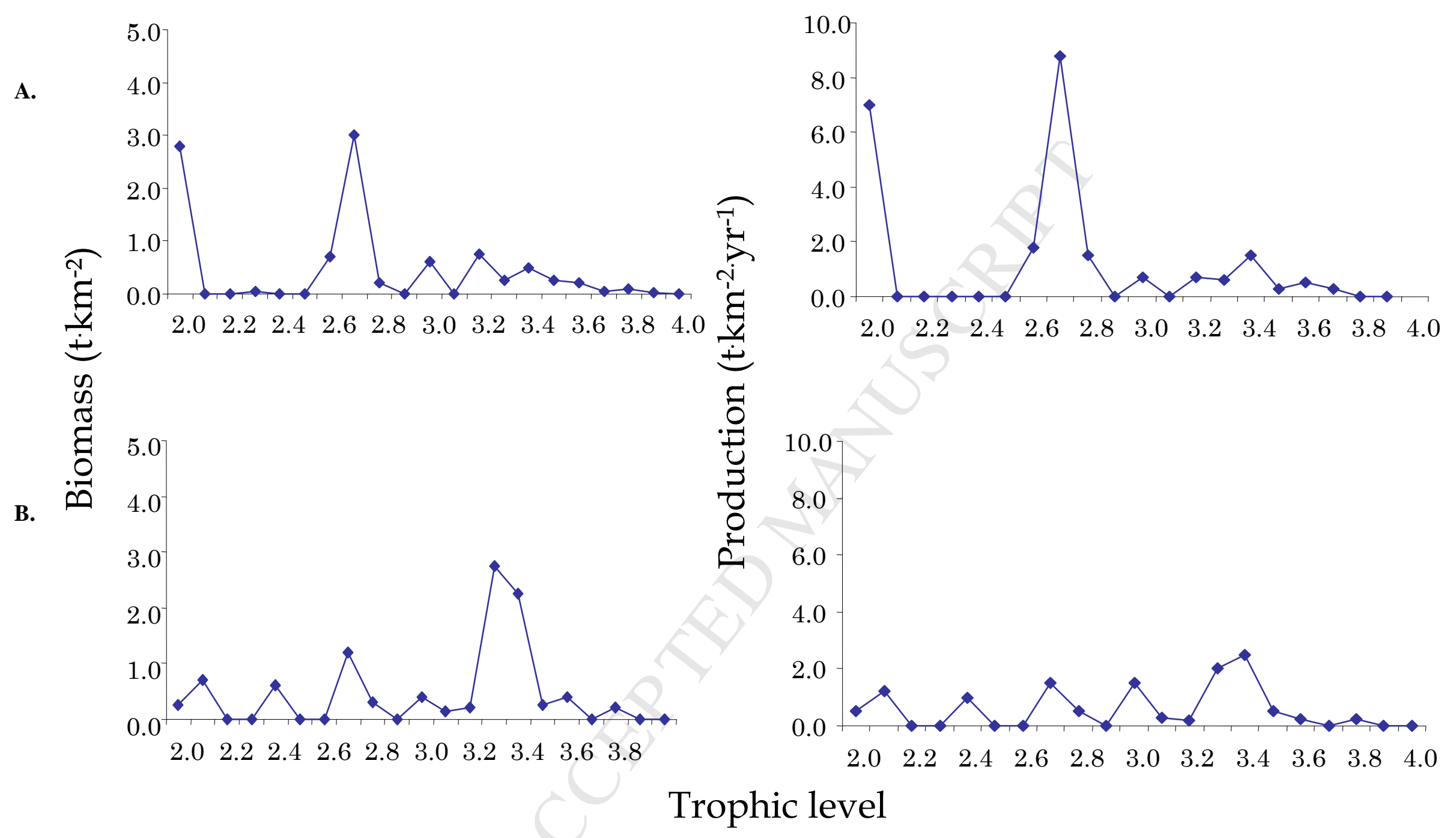

Figure 3

Villanueva 


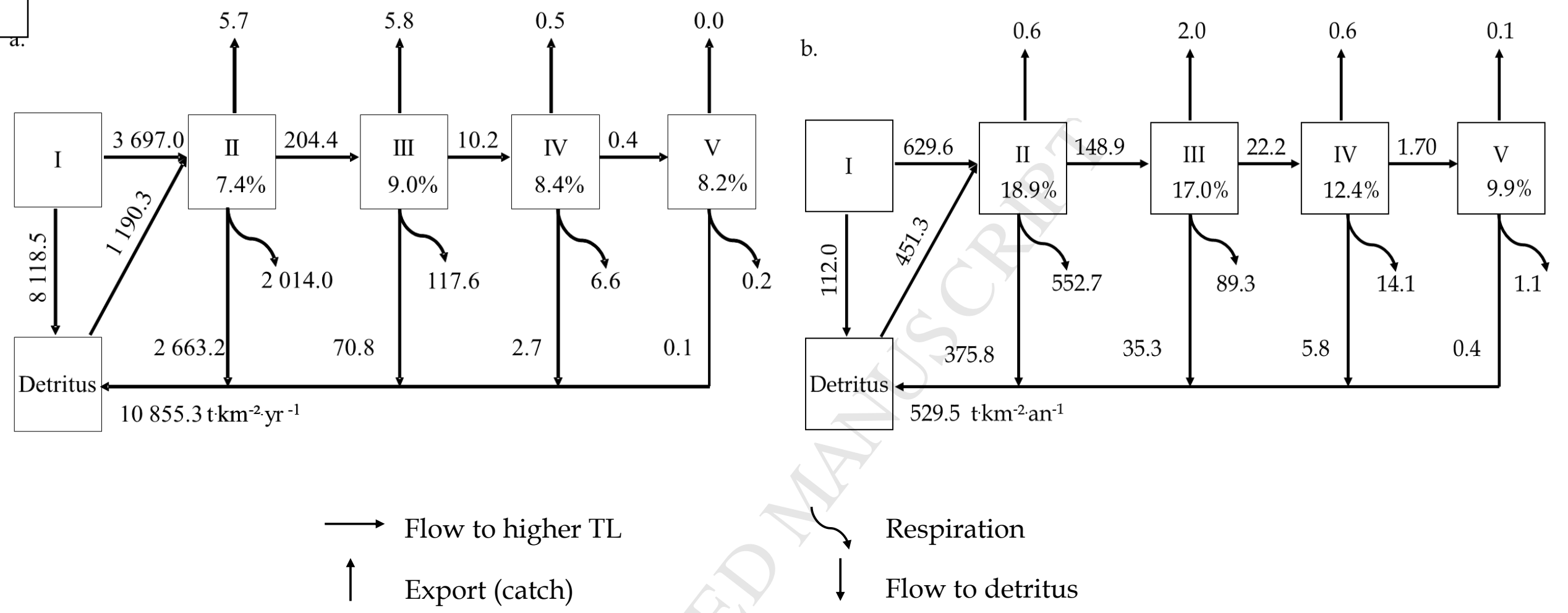

Figure 4

Villanueva 